This item was submitted to Loughborough's Research Repository by the author.

Items in Figshare are protected by copyright, with all rights reserved, unless otherwise indicated.

\title{
Perceived quality of internships and employability perceptions: the mediating role of career-entry worries
}

PLEASE CITE THE PUBLISHED VERSION

https://doi.org/10.1108/ET-02-2020-0037

PUBLISHER

Emerald

VERSION

AM (Accepted Manuscript)

PUBLISHER STATEMENT

This paper was accepted for publication in the journal Education + Training and the definitive published version is available at https://doi.org/10.1108/ET-02-2020-0037.

\section{LICENCE}

CC BY-NC 4.0

\section{REPOSITORY RECORD}

Ebner, Katharina, Roman Soucek, and Eva Selenko. 2021. "Perceived Quality of Internships and Employability Perceptions: The Mediating Role of Career-entry Worries”. Loughborough University. https://hdl.handle.net/2134/13536431.v1. 


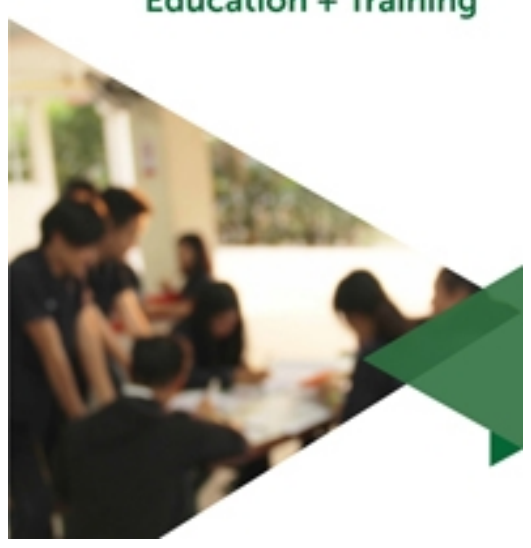

Perceived Quality of Internships and Employability Perceptions: The Mediating Role of Career-Entry Worries

\begin{tabular}{|r|l|}
\hline Journal: & Education + Training \\
\hline Manuscript ID & ET-02-2020-0037.R3 \\
\hline Manuscript Type: & Research Paper \\
\hline Keywords: & $\begin{array}{l}\text { employability, graduate students, work experience, internship, career- } \\
\text { entry worries }\end{array}$ \\
\hline \multicolumn{2}{|l}{} \\
\hline
\end{tabular}


Abstract

Purpose: This study illuminates the assumption that internships facilitate labor market entry and answers the question of why internships have a positive effect on students' selfperceived employability. It is assumed that internships enable more positive employability perceptions by reducing career-entry worries - the worries of not finding a suitable job or not being able to obtain a satisfactory career.

Design/methodology/approach: A two-wave study among graduate students currently in an internship investigated these relationships. Data on career-entry worries, perceived employability and an evaluation of the internship were collected from 80 students (mean age: 24.6 years, $68 \%$ female) from various fields of study aiming at both Bachelor's and Master's degrees.

Findings: The results showed that positively-evaluated internships contributed to graduates' self-perceived employability by means of reduced career-entry worries over an eight week period.

Originality: By considering graduates' career-entry worries - the perceived uncertainty about finding an 'appropriate' career in the future - the authors introduce a new concept to the career literature and show that these worries are significant in terms of self-assessed employability.

Keywords: career-entry worries, employability, graduate students, work experience, internship 


\section{Perceived Quality of Internships and Employability Perceptions:}

\section{The Mediating Role of Career-Entry Worries}

Starting out into a career as a university graduate is getting increasingly difficult, not only due to the looming economic crisis (Reidy, 2020), but due to ambitious expectations that employers place on applicants (Cappelli, 2012). According to the International Labour Organization's World Employment and Social Outlook, higher education alone no longer works as a guarantee for a good job, let alone as a protector against unemployment (International Labour Organization, 2017). What has been claimed to be effective for successful career entry and beneficial for further career development, is work experience - on top of a degree education. Indeed, one key finding from a survey among graduate employers in the UK was that graduates without previous work experience would have "little or no chance of receiving a job offer" (High Fliers Research, 2017, p. 24). This is echoed by employers and the experience of students in other countries (AlmaDiploma, 2020; Groll, 2018; Van der Werff and Bisschop, 2016). Accordingly, research on students who gained work experience during their study, confirms its positive effects on students' marketability (Gault, Leach \& Duey, 2010), speed of finding employment (Callanan and Benzing, 2004) and starting salary (Reddy and Moores, 2012), which seems to confirm the link between work experience and employability.

Yet, despite a considerable volume of empirical studies on the effect of placements, internships or work experience on graduates' employability (Brooks and Youngson, 2016; Mason et al., 2009; Taylor and Hooley, 2014), theoretical frameworks that account for the intervening psychological processes are rare. Most studies focus on the knowledge, skills and ability gained from work experience (Green and Farazmand, 2012; Messer, 2018; Wilton, 2012). Others propose that placements boost specific forms of self-efficacy (Bates et al., 2013; Lucas et al., 2009). However, work experience (or internships or placements) is not only helpful because it adds knowledge, skills and abilities, its beneficial effects might also 
consist of alleviating concerns, insecurities and worries about the future. This study will highlight the particular issue of career-entry worries which are referred to within the career literature, but have not yet been formally considered in explaining the positive effect of work experience. We define career-entry worries as the uncertainty of students about being able to successfully establish themselves professionally after graduation and thus laying the foundations for a successful career. Career-entry worries indicate that careers are perceived as far from secure by university graduates, despite having, on average, better job conditions and lower unemployment rates than people without degrees. They constitute a real, everyday concern for graduates (e.g., Page, 2014).

The present study thus highlights an overlooked aspect of the beneficial effects of internships on employability perceptions: the role of career-entry worries. By giving attention to career-entry worries, we expand current discussions on the beneficial effects of students' internship experiences when predicting future employment outcomes. We propose that careerentry worries play a central role in students' perceptions of their labor market skills, but that internships can reduce these. Indeed, students could purposely do an internship to reduce their insecurities and career worries. According to the career-resources model (Hirschi, 2012), work experience can be understood as enhancing human, social as well as psychological capital, which in turn drives perceived employability. The current study proposes that work experience not only enhances skills, knowledge, and networks, but also reduces career-entry worries and thereby enhances employability perceptions. We thereby build on earlier findings on the relationship between work experience and employability, which were ambiguous (Wilton, 2012). We additionally propose that internships need to have specific characteristics to reduce career-entry worries and to positively affect employability perceptions for subsequent careers. The focus will thus be on the internship's quality and how much it actually promotes employability (see Pan et al., 2018). From a cognitive point of view, a positive evaluation of the learning outcomes during an internship will inform students' 
awareness of possessing the right skills for the labor market and of being prepared for a future career, and that this reduces acute career-entry worries.

Our contribution to the literature thus is twofold: First, we intend to confirm that internships unleash their beneficial effects on graduates' perceived employability only if they are positively-evaluated. Second, by introducing career-entry worries, we not only identify a very real, yet overlooked, issue, but we also illustrate a potential mechanism to better comprehend the positive effects of internships..

\section{A Predictor of Employability Perceptions: Graduates' Career-Entry Worries}

We propose that career-entry worries play a central role in how students perceive their employability. Although careers are multi-faceted and dynamic and subjective ideas about what makes a good career change over the course of a person's working life (e.g., Jung and Takeuchi, 2018), students are still concerned about starting their careers with the wrong employer, job, or occupation (Kelly and Lee, 2002; Stead and Watson, 1993).

The concern of not finding appropriate employment after graduation is what we define as career-entry worries. The term 'appropriate' refers to a job that matches graduates' skills, degree, and financial needs. This specific type of fear is widely reported in career-counseling practice (e.g., Page, 2014) and seems not unfounded in today's unpredictable labor market, where graduates are often found to be under-employed (Nabi, 2003). Particularly in contexts where studying comes at a high (financial) cost, there is an expectation that an appropriate career would make those sacrifices worthwhile.

Conceptually, career-entry worries describe the future-directed affective and cognitive apprehension that the start of a career will fail, and that one will not find a suitable job. Like the more general concept of career-concerns (Creed et al., 2009), career-entry worries are characterized by the persistent apprehension of a negative future and contain a considerable uncertainty component. This apprehension is a key element of stress: “... not knowing whether an event is going to occur can lead to a long, drawn-out process of appraisal and re- 
appraisal, generating conflicting thoughts, feelings and behaviors [...]" (Lazarus and Folkman, 1984, p. 92). In fact, starting a career is a highly meaningful event, constituting one of the normative developmental tasks young people are expected to achieve in industrialized societies (Heckhausen et al., 2010), which would make a potential failure even more stressful (Lazarus and Folkman, 1984). This apprehension of a potentially negative work-related future renders career-entry worries similar to other future-directed worries at work, such as the fear of becoming unemployed during times of job insecurity (De Witte, 1999), or retirement anxiety (Macewen et al., 1995).

Career-entry worries are important to look at because they influence how people feel, think and approach their future careers. According to the affect-as-information hypothesis (Clore et al., 2001), worries can serve a mental informative purpose themselves, and used as a heuristic when estimating the likelihood of future events. Furthermore, worries about threatening events (such as under-employment), can undermine creativity and innovation, according to the threat-rigidity hypothesis (Staw et al., 1981; Van Hootegem et al., 2019). This is particularly detrimental to graduate students, who are required to have confidence in their future capabilities and show creativity when finding a job. In that regard, we expect that worry about career-entry leads people to be more pessimistic about their own employability which is defined as the belief of possessing personal characteristics, experiences and skills which are important in the labor market (Gunawan et al., 2019) - lower.

\section{Graduates' Career-Entry Worries: The Contribution of High-Quality Internships}

Having established that career-entry worries are likely to play a decisive role in predicting employability, the question is what can be done to reduce them. One way to reduce uncertainty is to regain control. Work experience in the form of an internship is a great way of regaining control over an uncertain future career, for several reasons.

Firstly, the process of applying for an internship provides training in the application process for the desired field of work, and teaches about the qualifications and social skills that 
employing organizations look for (Liu et al., 2014). This replaces rather vague ideas with clear experience (Kapareliotis et al., 2019) and so reduces uncertainties surrounding labor market entry. Secondly, the work experience itself provides graduates with a realistic jobpreview of work after graduation (Rose, 2018; Zehr and Korte, 2020) and could be understood as a trial-run transition (Inceoglu et al., 2019). Thereby, the prospect of working in a professional context becomes less unknown and less of a threat. Finally, any work experience can be understood as an opportunity to broaden a person's skills, knowledge and repertoire of problem-solving strategies (Brooks et al.,1995; Inceoglu et al., 2019; Jones et $a l ., 2017)$. Any challenge and task that is successfully mastered strengthens the belief that one will be able to handle oneself in professional surroundings, which fosters the appraisal of coping abilities and skills for future job challenges (Bandura, 1982).

Yet, internships vary in their quality and not all types of work experience might calm graduates' career-entry worries to an equal degree. The quality of an internship will play a crucial role for individuals' career-entry worries for several reasons. When graduates evaluate whether an internship is suitable for their subsequent career, they will, first, consider their satisfaction with it. According to the well-documented relationship between satisfaction and performance (Judge et al., 2001), students who have a rather satisfying work experience will not only show better performance in their job, but will also transfer the learning content to their daily lives better (e.g., Jodlbauer et al., 2011). A satisfying internship that gives graduates more confidence in their abilities, will thus reduce potential negative feelings such as career-entry worries, and the uncertainty and anxiety associated with it. Secondly, when establishing the quality of a placement, graduates also evaluate their learning outcomes which in turn will impact their career-worries: the degree to which graduates perceive their internship as a source of skill, ability and knowledge gain will shape their estimation of being qualified for a subsequent job and, hence, their perceptions on finding an adequate job. Finally, in order to deliver clarity on subsequent labor market entry and to reduce uncertainty 
and worries, the internship needs to be perceived as useful for the prospective job. If students evaluate their internship as useful for their future career, it will also contribute to the reduction of career-entry worries.

A high-quality internship that contributes to graduates' evaluation of possessing the 'right skills' for the labor market, will not only reduce career-entry worries but also directly influence their employability perceptions. There is a significant amount of research on the positive relationship of internships on students' employability perceptions. For example, Jackson (2013) surveyed a sample of students completing work placements, internships and work experiences and found that students reported a significant increase in perceived employability skills such as self-management in the workplace or problem-solving skills. Likewise, work placements were demonstrated to have significant value-added effects on employability skills, such as the ability to work in teams, self-confidence, or leadership (Wilton, 2012; Messer, 2018).

Essentially, graduates' employability perceptions comprise two things: the estimation of their chances in the labor market due to the degree program and the university they are enrolled in, and their self-perceived value in the job market, due to skills and other personal attributes (Rothwell et al., 2008). The latter estimation might be particularly strongly influenced by work experience: it is likely to undergo a profound change during an internship (Salancik and Pfeffer, 1978). During their internships, graduates will get feedback on their skills and competencies, either formally or on a day-to-day basis. Also, they will learn about adequate qualifications and necessary skills in a desired field of work (Zehr and Korte, 2020). Finally, their perspective of being able to address challenges at work in the future due to personal attributes and abilities, will change by successfully accomplishing work assignments during their internship, which are all supposed to foster graduates' perception of the social and human capital they possess, their confidence in their skills and, hence, their belief in being employable (Bandura, 1977; Rothwell et al., 2008). 


\section{High-Quality Internships: Considering Confounding Variables}

Based on literature on learning and training transfer and internship outcome research, we postulated that career-entry worries might erode the perception that one is employable, while high-quality internships reduce the fear that one might not find an adequate entry into the labor market. Yet, there are several features of the organization, such as the organizational climate, its culture, or the fit between the employee and the organization, which will additionally influence the evaluation of training and learning experiences (Zumrah and Boyle, 2015). We thus consider these factors as confounding variables in the relationship between high-quality internships, career-entry worries and employability.

One factor that plays a key role in how graduates evaluate their internship quality is positive affect. The affective experiences of graduates during the internship directly affect the evaluation of their internships. For example, the experience of grumpy colleagues and lonely lunches will likely make trainees feel uncomfortable or unhappy, probably leading to a more critical evaluation of the internship (cf. Burke and Hutchins, 2007) - and vice versa, positive affective states during the internship might lead to an over-estimation of the internship's quality. Furthermore, affective states have been found to influence learning outcomes: experiencing frequent positive emotions (e.g. feeling enthusiastic and cheerful or feeling calm) is assumed to broaden attention and make learners more receptive to new experiences (Fredrickson, 2004; Reschly et al., 2008). Thus, positive affect can lead to better knowledgegain during the internship and not controlling for positive affect might contribute to an overestimation of the learning experience during the internship.

The second variable we consider as confounding variable is perceived personenvironment fit. The evaluation of an internship will be affected by how individuals perceive their fit with the organization (Betz and Judge, 1994; Awoniyi et al., 2002): the more people feel they 'fit', the more they will see opportunities to learn and grow. Person-environment fit perceptions might thus influence graduates' feelings of being prepared for their labor market 
entry. Indeed, research shows that the misfit between the demands people encounter at work and their abilities has been related to increased stress perceptions (Edwards, 1996). Similarly, we expect that students who perceive a mismatch between the demands of their internship and their abilities will experience a surge in career-entry worries

The inclusion of affective experiences and perceptions of person-environment fit as boundary factors leads to the first hypothesis::

Hypothesis 1: Internships that are positively-evaluated reduce career-entry worries (Hypothesis 1a) and increase employability perceptions (Hypothesis 1b) over and above positive affective states and person-environment fit.

\section{The Indirect Effect of High-Quality Internships on Perceived Employability via Career-}

\section{Entry Worries}

We not only propose that high-quality internships will directly influence career-entry worries and employability, but we also presume an indirect effect: high quality internships will reduce career-entry worries, and thereby enhance employability perceptions.

The literature provides some support for this assumption. For example, De Cuyper and colleagues (2008) suggest that job insecurity - the worry of losing one's job (Mauno et al., 2001) - plays a mediatory role in the affective well-being and employability relationship. To the degree that job insecurity and career-entry worries are comparable (as they are both future-oriented employment worries with a high uncertainty component) this might suggest that career-entry worries act as an explanatory factor in the relationship between internship quality and employability. Comparing the insecurity of employees about maintaining a job (job insecurity), with the concerns of graduating students about not finding an appropriate job after their studies (career-entry worries), Spurk and colleagues (2016) also demonstrate a mediating mechanism which explains the effects of positive career experiences in the context of employability perceptions. Further, as one possible route to employability, Van Emmerik and colleagues (2012) suggested that an individual's perception of job opportunities mediates 
the link between job resources and employability, and we propose that a person who perceives a lot of job opportunities is also less worried about entering a career. Finally, Alisic and Wiese (2020) recently found that doing an internship (which they would refer to as workrelated self-management behavior) decreases perceived career insecurity via increases in positive perception of one's future development. This lends support for our hypothesis that career-entry worries act as an inhibitor to developing positive employability perceptions, particularly when comparing career insecurity as a 'feeling of powerlessness' to maintaining continuous employability (Colakoglu, 2011, p. 50) and the fear of not reaching career goals (Höge et al., 2012) with career-entry worries as the fear of not finding an appropriate career after graduation.

In this way, career-entry worries are likely to function as the connecting bridge between internship experiences and employability perceptions. To test this assumption more explicitly we postulate a second hypothesis:

Hypothesis 2: The effect of positively-evaluated internships on graduates' selfperceived employability will be mediated by career-entry worries.

\section{Method}

\section{Procedure and Study Design}

The study targeted students who were engaged in an internship at the time of data collection. They were approached by e-mail invitations which were sent to universities, companies and labor unions in Germany and Switzerland, posts in relevant newsgroups of professional online networks, and announcements in social networks, online communities dedicated to career interventions and universities' career service trainee networks. In line with the requirements of the ethics committee of the department where the study was carried out, the study took into account any relevant legal provisions, in particular with regard to data protection, and additional measures were taken to minimize the risks to which respondents may have been exposed. Specifically, the online data collection did not proceed without 
respondents' explicit consent to an ethics note (regarding, for example, anonymity, voluntariness, and data protection issues). There was no incentive for participation in the study.

In accordance with requirements of numerous study programs in Germany, which stipulate the compulsory completion of at least a six-week internship in order to acquire practical knowledge (internships that are not a compulsory part of one's studies usually also span a period of six to eight weeks), the survey period was precisely defined: Measurement point 1 was set at the first week of the winter term's semester break, measurement point 2 was scheduled eight weeks later, to ensure that students in the sample had spent a sufficient amount of time in the internship and were able to judge their work experience realistically. Career-entry worries, perceived employability and the evaluation of the internship were assessed at both measurement points of the study. The control variables were assessed once.

\section{Sample}

80 students participated in our study at both measurement points. They were between 20 - 40 years old $(M=24.59, S D=3.25)$. Most of the participants were female $(68 \%)$.

Participants were enrolled in the German higher education system. 51.3\% of the participants aimed for a Bachelor's degree, $45.0 \%$ a Master's degree, and 3.7\% other degrees, such as state examinations. The average number of semesters was 5.44 for Bachelor students $(S D=$ 2.20) and 3.42 for Masters students $(S D=1.56)$. The sample comprised students enrolled in law and business schools (62.5\%), arts and humanities (12.5\%), engineering (8.8\%), mathematics and the natural sciences $(6.3 \%)$, med school and health sciences $(2.3 \%)$ and other fields of studies (7.5\%). The majority was enrolled in universities $(82.5 \%)$ and $17.5 \%$ were enrolled in universities of applied sciences.

On average, the respondents had earned 98.61 ECTS points $(S D=55.13)$, with an average grade of 1.93 in the German system $(S D=0.51)$, which ranges from 1 (very good / outstanding achievement) to 5 (not sufficient / failed). The majority conducted their internship 
in their home country, Germany (except four students from other German-speaking countries), $3.8 \%$ of the sample had moved abroad temporarily for their internship.

\section{Measures}

\section{Evaluation of the internship.}

Students' appraisal of their internship was assessed using the Questionnaire for Professional Training Evaluation (Q4TE; Grohmann and Kauffeld, 2013), a widely-used measure in recent training and transfer literature with German-speaking samples (e.g., Massenberg et al., 2015; Diethert et al., 2015). We used three of its subscales, assessing participants' overall satisfaction with the internship, amount of skills and knowledge that they required in their internship, and a rating of its overall utility for the future, on an 11-point scale, ranging from $0 \%$ (completely disagree) to $100 \%$ (completely agree). As indicated by the scale authors, these three two-item subscales form a compound short-term evaluation measure (Grohmann and Kauffeld, 2013). To fit the context, the six items of the original scale were rephrased, with the word 'training' being replaced by 'internship, and 'work' by 'study' (e.g. "I will keep the internship in good memory." or "I learned a lot of new things in the internship.”). The reliability of the scale was good with Cronbach Alpha's of .87 (Time 1) and .88 (Time 2).

Career-entry worries. Career-entry worries were assessed with items that lean on Borg's (1992) and Borg and Elizur's (1992) conception of job insecurity. The original job insecurity items assess the worries that individuals experience about losing their job and estimations about the likelihood of keeping their job. To consistently adapt this measure, we took the 10-item German version of Borg's (1992) scale and replaced (1) any expression concerning "losing a job" with the expression "not finding a suitable job" and (2) the expression "likelihood of keeping a job" with the expression "likelihood of getting a suitable job”. Thereby, the term 'suitable' was important, as probably every student could find employment in an under-qualified profession. Two items from the original scale ("I look 
forward with confidence to the introduction of new technologies." and "I clearly know my chances for advancement in the coming years.") were not deemed appropriate for the situation of graduate students and were not transferred. This resulted in a scale consisting of eight items, to which respondents had to indicate their agreement or disagreement on a 7-point Likert scale. The items of this scale were re-coded, so that high values indicated high careerentry worries. Example items are "The thought of not finding a suitable career-entry worries me." or "The prospect of not finding a suitable job concerns me.". The internal reliability of the career-entry worries scale was good, both at Time $1(\alpha=.90)$ and Time $2(\alpha=.91)$.

Self-perceived employability. To assess self-perceived employability, we used a shortened version of the Self-Perceived Employability Scale for students (Rothwell et al., 2008) in a German translation. In particular, we used four items from the internal employability subscale. This subscale assesses respondents' estimation of their internal employability attributes, such as skills and abilities, using a 5-point Likert-style scale from 1 (strongly disagree) to 5 (strongly agree). Example items are: "The skills and abilities that I possess are what employers are looking for." and "I feel I could get any job so long as my as my skills and experience are reasonably relevant.". The internal consistency of the internal employability scale was acceptable at both measurement points $\left(\alpha_{\mathrm{T} 1}=.61\right.$ and $\left.\alpha_{\mathrm{T} 2}=.70\right)$.

Control variables. The following aspects were assessed as covariates: affective states during the internship and person-environment fit. As additional control variables, we considered gender and age, GPA, number of previous internships and the number of credits earned during studies.

Affective states during the internship were assessed with a German translation of the Multi-Affect Indicator by Warr and colleagues (Warr et al., 2014). The Multi-Affect Indicator measures job-related affects considering the level of activation (high - low) and the affective valence (positive - negative). In the present study, positive affective states of low and high activation were considered, since those are particularly important in the work context and 
adequately fit the state of high energy and activity during internships. Participants had to indicate how frequently they experienced four high-activation pleasant affective states (e.g. feeling enthusiastic) and four low-activation pleasant affective states (e.g. feeling comfortable) during the previous week of their internship, on a 7-point scale ranging from 1 (never) to 7 (always). The assessment of participants' affective states took place at Time 2, to control for the potentially confounding effect on the evaluation of the internship at Time 2 , since research shows that students evaluate their internship experience significantly more positively than they would have expected at the beginning of their internship (Neelam et al., 2019). Cronbach's Alpha in the present study confirmed moderately satisfactory internal consistencies of subscales with .58 (high activation positive affect) and .86 (low activation positive affect), which is comparable to the reliabilities found by the scale's authors, indicating an accurate translation which was well-adapted to the German language.

Person-environment fit comprises the facets of Person-organization fit, Needs-supplies fit, and Demands-abilities fit, which were assessed with a validated German translation of Cable and DeRue's (2002) measures of perceived fit at work (Haustein, 2016). Fit perceptions were measured on a 5-point scale, ranging from 1 (to a very little extent) to 5 (to a very large extent). Respondents were asked to rate their agreement to nine items (three for each subscale) by thinking of the organization they worked for and their everyday experiences in the respective organization. A sample item is "The things that I value in life are very similar to the things that my organization values." (person-organization fit; item derived from the original English scale). Within the study sample, the subscales of this widely-used measure showed good reliability with .96 (person-organization fit), .91 (needs-supplies fit), and .87 (demands-abilities fit), which equal the consistencies above .80 of the original English version (Cable and DeRue, 2002). We controlled the potential confounding effect of personenvironment fit perceptions on the evaluation of the internship at Time 1, considering previous findings that perceptions of fit measured at organizational entry are not stable but 
grow through socialization processes within the employing organization (De Cooman et al., 2009; Cooper-Thomas et al., 2004).

\section{Statistical Analyses}

Analyses were conducted using R 3.6.1 (R Core Team, 2019). We first conducted a hierarchical regression analysis predicting career-entry worries at Time 2 while controlling for career-entry worries at Time 1 . This approach controls for between-subject effects of careerentry worries at the beginning of the internship and, accordingly, the regressions predict the change in career-entry worries throughout the internship; the same procedure was applied to perceived employability. The predictors were included separately for both measurement times in the regressions. For example, in predicting employability, the effect of career-entry worries at Time 1 represents the baseline measurement, while the effect at Time 2 indicates the influence of the change in career-entry worries since Time 1 on the change of employability at Time 2. For testing the hypotheses, the effect of career-entry worries at the second measurement time is particularly important, since this predictor represents a within-subject effect and allows first conclusions to be drawn about the causality relationships (cf. Cohen et al., 2003).

\section{Results}

\section{Preliminary Analyses}

We conducted preliminary analysis to decide whether or not to include the control variables, as described in the methods section. We considered gender and age, GPA, number of previous internships and the number of credits earned during studies as control variables. We also included possible confounds as covariates, namely positive affective states and person-environment fit. Since the control and the confounding variables had no influence and there was no substantial difference in the analysis' results with and without these variables, we conducted the main statistical analysis without control (e.g. gender, age) and confounding variables (affective states and person-environment fit). 


\section{Correlations of Measures}

First, an inspection of the Pearson correlations of the variables in the study was carried out (Table 1). The evaluation of the internship at Time 1 was not correlated with career-entry worries at Time $1, r=-.12, p=.300$, and perceived employability at Time $1, r=.19, p=.100$, but was positively associated with perceived employability at Time $2, r=.28, p=.016$. Also, the evaluation of the internship at Time 2 was associated with perceived employability at Time $2, r=.23, p=.046$. As expected, career-entry worries were negatively correlated with employability both at Time $1, r=-.58, p<.001$, and at Time $2, r=-.60, p<.001$.

Insert Table 1 about here

\section{The Effects of Internships on Career-Entry Worries and Perceived Employability}

Hypothesis 1 states that positively-evaluated internships reduce career-entry worries (Hypothesis 1a) and enhance self-perceived employability (Hypothesis 1b). In order to test Hypothesis 1a, we conducted a hierarchical regression analysis predicting career-entry worries at Time 2 (Table 2). In Model 1a, we included career-entry worries at Time 1 as well as evaluation of internship quality at Time 1 . Since we regressed career-entry worries at Time 2 on career-entry worries at Time 1, we predicted the change in career-entry worries during the internship. As might be expected, career-entry worries at Time 1 predicted career-entry worries at Time $2, b=0.70, p<.001$. The evaluation of internship quality at Time 1 had no influence on the change in career-entry worries, $b=-0.00, p=.945$. In Model $1 \mathrm{~b}$, we included the evaluation of internship quality for Time 2. Since Time 1 constitutes a baseline measurement, we were especially interested in the effect of the internship quality at Time 2, which indicates the change of the evaluation in the course of the internship. Model $1 \mathrm{~b}$ indicates that the evaluation of the internship at Time 2 is negatively related to career-entry 
worries, $b=-0.14, p=.015$. Thus, an increase in the evaluation of the internship, results in a decrease in career-entry worries, which supports Hypothesis 1a.

Insert Table 2 about here

Table 3 outlines the results of hierarchical regression analyses predicting self-perceived employability. Again, we regressed employability at Time 2 on employability at Time 1, thus, predicting the change in employability in the course of the internship. Model 2a included employability, evaluation of internship quality, and career entry worries at Time 1.

Employability at Time 1 was revealed as significant, $b=0.71, p<.001$, indicating the temporal stability of perceived employability. In Model 2b, we additionally included the evaluation of the internship. The results indicated that internship quality at Time 2 did not contribute to a higher perceived employability at Time $2, b=0.06, p=.173$. Thus, Hypothesis 1b was not supported.

Insert Table 3 about here

The Indirect Effect of Internship Quality on Perceived Employability via Career-Entry Worries

Hypothesis 2 states that a positive evaluation of an internship will reduce career-entry worries, which, in turn, increases employability perceptions over and above positive affective states and person-environment fit. In Model 2c, we extended the analysis by including careerentry worries at Time 2 , which contributes to the model fit, $\Delta R^{2}=0.04, p=.015$. The negative influence of career-entry worries on employability at Time $2, b=-0.23, p=.015$, indicates that lowered career-entry worries are associated with an increase in employability perceptions. To test Hypothesis 2 about the indirect effect of internship quality on perceived 
employability by way of career-entry worries, we conducted a causal mediation analysis following Imai, Keele and Tingley (2010). The analysis is based on Model 1b and Model 2c, and thus includes the control variables of low- and high-activated positive affective states and three dimensions of person-environment fit, as reported in Tables 2 and 3. The results support an indirect effect, $b=0.03, p=.022, C 195[0.003 ; 0.080]$, which confirmed Hypothesis 2 (Figure 1). Overall, a positive evaluation of internship quality leads to a decrease in careerentry worries, which, in turn, enhances perceived employability over and above positive affective states and estimations of person-environment fit during the internship.

Insert Figure 1 about here

\section{Discussion}

“[...] for students there's one anxiety that comes back again and again: will I find a job when I graduate?" (Page, 2014). The current study set out to introduce this anxiety of graduate students as career-entry worries to the literature. We argued that graduate students who worry more about not finding the right job would estimate their employability lower and we presumed that career-entry worries could be reduced by positive internship experiences. Based on the literature on affect at work, training transfer, and person-environment fit, we also predicted that internships that allow for satisfactory and positive learning experiences, would be able to reduce career-entry worries over and above positive affect and the fit of a person's values, needs and abilities with the employing organization.

The findings of a two wave-study among graduate students in Germany and Switzerland provided substantial support for some of these assumptions. First, career-entry worries were confirmed to play an explanatory role in predicting employability perceptions over time. We found that worrying about one's labor market entry impairs employability perceptions among graduate students. Additionally, we found that career-entry worries can be 
moulded by work experience. More importantly, we found that it was through the reduction in career-entry worries, that positively-evaluated internships contributed to an increase in employability perceptions. Just on its own, completing a high-quality internship did not lead to higher employability perceptions. Rather, it was the reduction of career-entry worries that was linked by positively-evaluated internships with improved employability perceptions. Therefore, we can make a rather strong case for the important role of career-entry worries on graduate students' employability perception and their transition into the labor market.

\section{Limitations and Future Research}

There are several limitations to our findings. First, the study consisted of a relatively small convenience sample of graduate students. Respondents were invited via e-mail and newsgroups or word-of-mouth by other students. This strategy might have failed to recruit those who worried too much or too little about their future labor market entry: People who worry too much or too little might not want to mentally engage with the content of our study (catchword 'career') or might not even take up an internship. The small number of respondents further implies that only relatively powerful effects could be detected (Fritz and MacKinnon, 2007), which limits the conclusions that can be drawn. In addition, the small sample size prohibited the application of structural equation modeling (SEM) which would have been ideal for identifying the suspected relationships in the data.

Secondly, we cannot draw robust conclusions about causality. Though our analyses relied on within-subject effects while controlling for between-subject effects (Montoya, 2020), we cannot completely rule out reverse causality, in that students who were less worried might have been more likely to have better experiences during their internships. Instead, preference should be given to study designs that allow for more robust causal conclusions, such as the study by Pan and colleagues (2018), who proposed and tested the indirect effect of interns' proactive personality on employability success by taking account of the internships' quality within a four wave-study. In contrast, the two-wave data of our study limits the 
conclusions that can be drawn about the proposed indirect effect; for a true test, at least three measurement points would be needed (Cole and Maxwell, 2003). At least the two-wave design reduces the chance that common method bias influenced our results (Podsakoff et al., 2003). Ultimately, it would be interesting to explore the role of career-entry worries as a moderator: pronounced career-entry worries might reduce the (positive) effect that internships could have on graduates' perceived employability.

Third, the self-report nature of the data might also have affected the findings. Since employability is related to career success (e.g., De Vos et al., 2011), it would have been interesting to include 'hard' measures of labor market entry success. There are some sound ways of measuring graduates' labor market entry success more objectively, and we encourage including information like the ratio of the number of applications for a job that were sent to employers compared to the number of positive reactions in the sense of invitations to interviews.

Despite these limitations, we believe that our research several new avenues for future studies that might be of interest to researchers in the areas of career-transitions into work, graduate employment and newcomer socialization.

\section{Practical Implications and Conclusion}

We believe we could make a strong case that career-entry worries among graduate students need to be taken seriously by universities and by organizations offering internships. Career-entry worries influence students' employability perceptions, as this study shows, but can be reduced by high quality internships. There are several practical lessons to be learned from these findings.

First of all, the finding that career-entry worries are a relevant concern for graduate students is important in itself. We have identified and provided a measure for a potentially common stressor among students, one that seems to be particularly relevant in the wake of the worldwide pandemic. Given the strained situation on the graduate job market and also the fact 
that mental ill-health is on the rise in student populations, student support services might want to pay extra attention to career-entry worries when providing counseling support (Newman et al.,1989; Thorley, 2017; Wendlandt and Rochlen, 2008).

Secondly, the study also shows that career-entry worries can be amended: namely by providing high quality internships, which are perceived as meaningful, satisfying and as a source of skill and knowledge. This highlights how important it is that internships are wellplanned and designed to deliver the right learning outcomes (e.g., Bauer et al., 2007; McManus and Feinstein, 2014). The responsibility for ensuring the quality of internship lies with organizations - but also with universities, in situations where internships form part of degree programs. Employers need to recognize that they can greatly influence whether trainees feel better prepared for the labor market entry through the internships they offer (Neelam et al., 2019). Offering a high-quality internship can also reflect positively on organizations themselves (through social media such as @ratemyplacement) and thereby make them more attractive for future job applicants.

There is an extensive knowledge base on how to improve the quality of internships already (see e.g. Baily et al., 2016 for common practice and suggestions). One possibility to enhance the learning experience would be to set specific learning objectives for the internship with the trainees (in particular various aspects of procedural and declarative knowledge) and have regular conversations about them (cf. Bhattacharya and Neelam, 2018). Other suggestions would be to sharpen interns' awareness of their learning process, for example by encouraging the use of self-reflective work-diaries. Also, regular supervision by a member of faculty has been shown to be beneficial (Baily et al., 2016).

But universities can do more to support their students in overcoming their career-entry worries, in particular by encouraging them to take responsibility for their career-entry, for example, by prompting them to actively look out for role models and to seek information and experiences that replace non-specific concerns with factual knowledge. Universities can help 
establish contact with employers (e.g. through brown paper talks, lecture series, career-fairs, etc.), and help students build confidence in finding role models or opportunities to gain adequate work experience, which counteracts vague worries, for example, by integrating workshops on "career-entry" or "career design" into their curricula, where possible measures on how to proactively and effectively shape students' labor market entry are presented. In conclusion, this research stresses the importance of high-quality internships from a psychological angle: internships have significant psychological benefits, in the form of reducing graduates' career worries. Having fewer career worries is important, as it can enhance graduates' confidence of finding a successful, sustainable career. 


\section{References}

Alisic, A. and Wiese, B. S. (2020), "Keeping an insecure career under control: the longitudinal interplay of career insecurity, self-management, and self-efficacy", Journal of Vocational Behavior, Vol. 120, 103431, available at https://doi.org/10.1016/j.jvb.2020.103431.

Awoniyi, E. A., Griego, O. V. and Morgan, G. A. (2002), "Person-environment fit and transfer of training", International Journal of Training and Development, Vol. 6 No. 1, pp. 25-35.

AlmaDiploma (2017), “XIV Indagine esiti a distanza dei diplomati. rapporto 2020.” [14 ${ }^{\text {th }}$ rapport on the destinations of graduate students], Associazione di Scuole AlmaDiploma, available at:

http://www.almadiploma.it/info/pdf/scuole/occupazione2019/Rapporto_2020_ESITI.pd f(accessed 10 May 2020)

Bandura, A. (1977), "Self-efficacy: toward a unifying theory of behavioral change", Psychological Review, Vol. 84 No. 2, pp. 191-215.

Bandura, A. (1982), "Self-efficacy mechanism in human agency”, American Psychologist, Vol. 37 No. 2, pp. 122-147.

Bailey, S. F., Barber, L. K. and Nelson, V. L. (2017), “Undergraduate internship supervision in psychology departments: use of experiential learning best practices", Psychology Learning \& Teaching, Vol. 16 No. 1, pp. 74-83.

Bauer, T. N., Bodner, T., Erdogan, B., Truxillo, D. M. and Tucker, J. S. (2007), "Newcomer adjustment during organizational socialization: a meta-analytic review of antecedents, outcomes, and methods", Journal of Applied Psychology, Vol. 92 No. 3, pp. 707-721.

Bates, M., Thompson, C. and Bates, L. J. (2013), "Not all dimensions of work self-efficacy are equal: understanding the role of tertiary work placements in the development of the 
elements of work self-efficacy", Journal of Cooperative Education and Internships, Vol. 47 No. 1, pp. 19-30.

Betz, Jr, R. D. and Judge, T. A. (1994), "Person-organization fit and the Theory of Work Adjustment: implications for satisfaction, tenure, and career success", Journal of Vocational Behavior, Vol. 44 No. 1, pp. 32-54.

Bhattacharya, S. and Neelam, N. (2018), "Perceived value of internship experience: a try before you leap", Higher Education, Skills and Work-Based Learning, Vol. 8 No. 4, pp. 376-394.

Borg, I. (1992), „Ueberlegungen und Untersuchungen zur Messung der subjektiven Unsicherheit der Arbeitsstelle", Zeitschrift fuer Arbeits- und Organisationspsychologie, Vol. 36 No. 3, pp. 107-116.

Borg, I. and Elizur, D. (1992), "Job insecurity: correlates, moderators and measurement”, International Journal of Manpower, Vol. 13 No. 2, pp. 13-26.

Brooks, L., Cornelius, A., Greenfield, E. and Joseph, R. (1995), “The relation of careerrelated work or internship experiences to the career development of college seniors", Journal of Vocational Behavior, Vol. 46 No. 3, pp. 332-349.

Brooks, R. and Youngson, P. L. (2016), “Undergraduate work placements: an analysis of the effects on career progression", Studies in Higher Education, Vol. 41 No. 9, pp. 1563 1578.

Burke, L. A. and Hutchins, H. M. (2007), “Training transfer: an integrative literature review", Human Resource Development Review, Vol. 6 No. 3, pp. 263-296.

Cable, D. M. and DeRue, D. S. (2002), “The convergent and discriminant validity of subjective fit perceptions", Journal of Applied Psychology, Vol. 87 No. 5, pp. 875-884.

Callanan, G. and Benzing, C. (2004), “Assessing the role of internships in the career-oriented employment of graduating college students”, Education + Training, Vol. 46 No. 2, pp. 82-89. 
Cappelli, P. (2012), Why good people can't get jobs. The skill gap and what companies can do about it, Wharton Digital Press, Philadelphia, PA.

Clore, G. L., Gasper, K. and Garvin, E. (2001), “Affect as information.” Forgas, J. P. (Ed.), Handbook of affect and social cognition, Lawrence Erlbaum Associates, Mahwah, NJ, pp. 121-144.

Cohen, J., Cohen, P., West, S. G. and Aiken, L. S. (2003), Applied multiple regression/correlation analysis for the behavioral sciences, Lawrence Erlbaum Associates, London.

Colakoglu, S. N. (2011), “The impact of career boundarylessness on subjective career success: the role of career competencies, career autonomy, and career insecurity", Journal of Vocational Behavior, Vol. 79 No. 1, pp. 47-59.

Cole, D. A. and Maxwell, S. E. (2003), “Testing mediational models with longitudinal data: questions and tips in the use of structural equation modeling", Journal of Abnormal Psychology, Vol. 112 No. 4, pp. 558-577.

Cooper-Thomas, H. D., Van Vianen, A. and Anderson, N. (2004), “Changes in personorganization fit: the impact of socialization tactics on perceived and actual P-O fit”, European Journal of Work and Organizational Psychology, Vol. 13 No. 1, pp. 52-78.

Creed, P. A., Fallon, T. and Hood, M. (2009), “The relationship between career adaptability, person and situation variables, and career concerns in young adults", Journal of Vocational Behavior, Vol. 74 No. 2, pp. 219-229.

De Cuyper, N., Bernhard-Oettel, C., Berntson, E., De Witte, H. and Alarco, B. (2008), “Employability and employees’ well-being: mediation by job insecurity", Applied Psychology, Vol. 57 No. 3, pp. 488-509.

De Cooman, R., De Gieter, S., Pepermans, R., Hermans, S., Du Bois, C., Caers, R. and Jegers, M. (2009), "Person-organization fit: testing socialization and attraction-selectionattrition hypotheses”, Journal of Vocational Behavior, Vol. 74 No. 1, pp. 102-107. 
De Vos, A., De Hauw, S. and Van der Heijden, B. I. (2011), “Competency development and career success: the mediating role of employability", Journal of Vocational Behavior, Vol. 79 No. 2, pp. 438-447.

De Witte, H. (1999), “Job insecurity and psychological well-being: review of the literature and exploration of some unresolved issues", European Journal of Work and Organizational Psychology, Vol. 8 No. 2, pp. 155-177.

Diethert, A. P., Weisweiler, S., Frey, D. and Kerschreiter, R. (2015), “Training motivation of employees in academia: developing and testing a model based on the theory of reasoned action”, Zeitschrift für Erziehungswissenschaft, Vol. 18 No. 1, pp. 29-50.

Edwards, J. R. (1996), “An examination of competing versions of the person-environment fit approach to stress”, Academy of Management Journal, Vol. 39 No. 2, pp. 292-339.

Fornell, C. and Larcker, D. F. (1981), "Evaluating structural equation models with unobservable variables and measurement error", Journal of Marketing Research, Vol. 18 No. 1 , pp. 39-50.

Fredrickson, B. L. (2004), "The broaden-and-build theory of positive emotions", Philosophical Transactions of the Royal Society B: Biological Sciences, Vol. 359 No. 1449, pp. 1367-1377.

Fritz, M. S. and MacKinnon, D. P. (2007), "Required sample size to detect the mediated effect", Psychological Science, Vol. 18 No. 3, pp. 233-239.

Gault, J., Leach, E. and Duey, M. (2010), “Effects of business internships on job marketability: the employers' perspective", Education + Training, Vol. 52 No. 1, pp. $76-88$.

Green, R. D. and Farazmand, F. A. (2012), “Experiential learning: the internship and live-case study relationship", Business Education \& Accreditation, Vol. 4 No. 1, pp. 13-23. 
Grohmann, A. and Kauffeld, S. (2013), "Evaluating training programs: development and correlates of the questionnaire for professional training evaluation", International Journal of Training and Development, Vol. 17 No. 2, pp. 135-155.

Groll, T. (2018), „Kein Job ohne Praktikum“, available at https://www.karriere.de/berufseinstieg-kein-job-ohne-praktikum/23043460.html (accessed 11 May 2020)

Gunawan, W., Creed, P. A. and Glendon, A. I. (2019), "Development and initial validation of a perceived future employability scale for young adults", Journal of Career Assessment, Vol. 27 No. 4, pp. 610-627.

Haustein, B. (2016), „Mitarbeiterbindung in einer öffentlichen Verwaltung “ [Committment in the Public Sector], unpublished master thesis, Friedrich-Alexander-Universität Erlangen-Nürnberg, Nürnberg.

Heckhausen, J., Wrosch, C. and Schulz, R. (2010), “A motivational theory of life-span development", Psychological Review, Vol. 117 No. 1, pp. 32-60.

High Fliers Research (2017), “The graduate market in 2017. Annual review of graduate vacancies \& starting salaries at Britain's leading employers”, available at https://www.highfliers.co.uk/download/2017/graduate_market/GMReport17.pdf (accessed 12 July 2017)

Hirschi, A. (2012), “The career resources model: an integrative framework for career counsellors", British Journal of Guidance \& Counselling, Vol. 40 No. 4, pp. 369-383

Höge, T., Brucculeri, A. and Iwanowa, A. N. (2012), "Karriereunsicherheit, Zielkonflikte und Wohlbefinden bei Nachwuchswissenschaftlerinnen und -wissenschaftlern“, Zeitschrift für Arbeits- und Organisationspsychologie, Vol. 56 No. 4, pp. 159-172.

Imai, K., Keele, L. and Tingley, D. (2010), “A general approach to causal mediation analysis”, Psychological Methods, Vol. 15 No. 4, pp. 309-334. 
Inceoglu, I., Selenko, E., McDowall, A. and Schlachter, S. (2019), “(How) Do work placements work? Scrutinizing the quantitative evidence for a theory-driven future research agenda", Journal of Vocational Behavior, Vol. 110 Part B, pp. 317-337.

International Labour Organization (2017), World employment and social outlook. Trends 2017, ILO: Geneva, available at http://www.ilo.org/wcmsp5/groups/public/--dgreports/---dcomm/---publ/documents/publication/wcms_541211.pdf(accessed 12 July 2017)

Jackson, D. (2013), “The contribution of work-integrated learning to undergraduate employability skill outcomes", Asia-Pacific Journal of Cooperative Education, Vol. 14 No. 2, pp. 99-115.

Jodlbauer, S., Selenko, E., Batinic, B. and Stiglbauer, B. (2012), "The relationship between job dissatisfaction and training transfer", International Journal of Training and Development, Vol. 16 No. 1, pp. 39-53.

Jones, F. R., Mardis, M. A., McClure, C. R., Ma, J., Ambavarapu, C. and Spears, L. I. (2017), "Work-integrated learning (WIL) in information technology", Higher Education, Skills and Work-Based Learning, Vol. 7 No. 4, pp. 394-407.

Judge, T. A., Thoresen, C. J., Bono, J. E. and Patton, G. K. (2001), “The job satisfaction-job performance relationship: a qualitative and quantitative review”, Psychological Bulletin, Vol. 127 No. 3, pp. 376-407.

Jung, Y. and Takeuchi, N. (2018), “A lifespan perspective for understanding career selfmanagement and satisfaction: the role of developmental human resource practices and organizational support”, Human Relations, Vol. 71 No. 1, pp. 73-102.

Kapareliotis, I., Voutsina, K. and Patsiotis, A. (2019), “Internship and employability prospects: assessing student's work readiness", Higher Education, Skills and WorkBased Learning, Vol. 9 No. 4, pp. 538-549. 
Kelly, K. R. and Lee, W. C. (2002), "Mapping the domain of career decision problems", Journal of Vocational Behavior, Vol. 61 No. 2, pp. 302-326.

Lazarus, R. S. and Folkman, S (1984), Stress, appraisal and coping, Springer Publishing Company, New York, NY.

Liu, S., Huang, J. L. and Wang, M. (2014), "Effectiveness of job search interventions: a metaanalytic review", Psychological Bulletin, Vol. 140 No. 4, pp. 1009-1041.

Lucas, W. A., Cooper, S. Y., Ward, T. and Cave, F. (2009), "Industry placement, authentic experience and the development of venturing and technology self-efficacy", Technovation, Vol. 29 No. 11, pp. 738-752.

Macewen, K. E., Barling, J., Kelloway, E. K. and Higginbottom, S. F. (1995), “Predicting retirement anxiety: the roles of parental socialization and personal planning", The Journal of Social Psychology, Vol. 135 No. 2, pp. 203-213.

McManus, A. and Feinstein, A. H. (2014), "Internships and occupational socialization: what are students learning?", Developments in Business Simulation and Experiential Learning: Proceedings of the Annual ABSEL Conference, Vol. 35, pp. 128-137.

Mason, G., Williams, G. and Cranmer, S. (2009), "Employability skills initiatives in higher education: what effects do they have on graduate labour market outcomes?", Education Economics, Vol. 17 No. 1, pp. 1-30.

Massenberg, A. C., Spurk, D. and Kauffeld, S. (2015), “Social support at the workplace, motivation to transfer and training transfer: a multilevel indirect effects model", International Journal of Training and Development, Vol. 19 No. 3, pp. 161-178.

Mauno, S., Leskinen, E. and Kinnunen, U. (2001), "Multi-wave, multi-variable models of job insecurity: applying different scales in studying the stability of job insecurity”, Journal of Organizational Behavior, Vol. 22 No. 8, pp. 919-937.

Messer, D. (2018), “Work placements at 14-15 years and employability skills", Education + Training, Vol. 60 No. 1, pp. 16-26. 
Montoya, A. K. (2020), The power of design: impact of experimental design outweighs impact of inferential methods on statistical power to detect indirect effects, preprint available at https://psyarxiv.com/gqryz/. doi:10.31234/osf.io/gqryz

Nabi, G. R. (2003), “Graduate employment and underemployment: opportunity for skill use and career experiences amongst recent business graduates", Education + Training, Vol. 45 No. 7, pp. 371-382.

Neelam, N., Bhattacharya, S., Kejriwal, V., Bhardwaj, V., Goyal, A., Saxena, A., Dhawan, D., Vaddi, A. and Choudaha, G. (2019), "Internship in a business school: expectation versus experience", Higher Education, Skills and Work-Based Learning, Vol. 9 No. 1, pp. 92-106.

Newman, J. L., Fuqua, D. R. and Seaworth, T. B. (1989), "The role of anxiety in career indecision: implications for diagnosis and treatment", The Career Development Quarterly, Vol. 37 No. 3, pp. 221-231.

Nunley, J. M., Pugh, A., Romero, N. and Seals, R. A. (2017), “The effects of unemployment and underemployment on employment opportunities: results from a correspondence audit of the labor market for college graduates", ILR Review, Vol. 70 No. 3, pp. 642669.

Page, L. (2014), "How to deal with employability anxiety", The Guardian, 19.05.2014, available at https://www.theguardian.com/education/2014/may/19/employment-anxietystudents-job-worry

Pan, J., Guan, Y., Wu, J., Han, L., Zhu, F., Fu, X. and Yu, J. (2018), “The interplay of proactive personality and internship quality in Chinese university graduates' job search success: the role of career adaptability", Journal of Vocational Behavior, Vol. 109, pp. $14-26$. 
Podsakoff, P. M., MacKenzie, S. B., Lee, J. Y. and Podsakoff, N. P. (2003), “Common method biases in behavioral research: a critical review of the literature and recommended remedies", Journal of Applied Psychology, Vol. 88 No. 5, pp. 879-903.

R Core Team (2019), The TR project for statistical computing, available at https://cran.rproject.org/bin/windows/base/old/3.6.1/

Reddy, P. and Moore, E. (2012), "Placement year academic benefit revisited: effects of demographics, prior achievement and degree programme", Teaching in Higher Education, Vol. 17 No. 2, pp. 153-165.

Reidy, T. (2020), “Recruitment is on hold'. The students graduating into the Covid-19 recession", The Guardian, 10.4.2020, available at https://www.theguardian.com/education/2020/apr/10/recruitment-is-on-hold-thestudents-graduating-into-the-covid-19-recession

Reschly, A. L., Huebner, E. S., Appleton, J. J. and Antaramian, S. (2008), “Engagement as flourishing: the contribution of positive emotions and coping to adolescents' engagement at school and with learning", Psychology in the Schools, Vol. 45 No. 5, pp. $419-431$.

Rose, P. S. (2018), "The intern to employee career transition: an outsiders perception of insider status", Journal of Career Development, Vol. 45 No. 6, pp. 566-579.

Rothwell, A., Herbert, I. and Rothwell, F. (2008), "Self-perceived employability: construction and initial validation of a scale for university students", Journal of Vocational Behavior, Vol. 73 No. 1, pp. 1-12.

Russell, J. A. (1980), “A circumplex model of affect”, Journal of Personality and Social Psychology, Vol. 39 No. 6, pp. 1161-1178.

Salancik, G. R. and Pfeffer, J. (1978), “A social information processing approach to job attitudes and task design”, Administrative Science Quarterly, Vol. 23 No. 2, pp. 224253. 
Spurk, D., Kauffeld, S., Meinecke, A. L. and Ebner, K. (2016), "Why do adaptable people feel less insecure? Indirect effects of career adaptability on job and career insecurity via two types of perceived marketability", Journal of Career Assessment, Vol. 24 No. 2, pp. 289-306.

Staw, B. M., Sandelands, L. E. and Dutton, J. E. (1981), “Threat rigidity effects in organizational behavior: a multilevel analysis", Administrative Science Quarterly, Vol. 26 No. 4, pp. 501-524.

Stead, G. B. and Watson, M. B. (1993)," How similar are the factor structures of the Career Decision Scale, the Career Decision Profile, and the Career Factors Inventory?", Educational and Psychological Measurement, Vol. 53 No. 1, pp. 281-290.

Taylor, A.R. and Hooley, T. (2014), "Evaluating the impact of career management skills module and internship programme within a university business school”, British Journal of Guidance \& Counselling, Vol. 42 No. 5, pp. 487-499.

Thorley, C. (2017), "Not by degrees. Improving student mental health in the UK's universities”, Institute for Public Policy Research, London, available at https://www.ippr.org/files/2017-09/1504645674_not-by-degrees-170905.pdf

Van der Werff, S. and Bisschop, P. (2016), „Studie en werk. SEO economisch onderzoek”, SEO-rapportnummer 2016-47, available at http://www.seo.nl/uploads/media/201647_Studie_Werk_2016.pdf (accessed 12 July 2017)

Van Emmerik, I. J. H., Schreurs, B., De Cuyper, N., Jawahar, I. M. and Peeters, M. C. (2012), "The route to employability: examining resources and the mediating role of motivation”, Career Development International, Vol. 17 No. 2, pp. 104-119.

Van Hootegem, A., Niesen, W. and De Witte, H. (2019), “Does job insecurity hinder innovative work behaviour? A threat rigidity perspective", Creativity and Innovation Management, Vol. 28 No. 1, pp. 19-29. 
Warr, P., Bindl, U. K., Parker, S. K. and Inceoglu, I. (2014), "Four-quadrant investigation of job-related affects and behaviours", European Journal of Work and Organizational Psychology, Vol. 23 No. 3, pp. 342-363.

Wendlandt, N. M. and Rochlen, A. B. (2008), “Addressing the college-to-work transition: implications for university career counselors", Journal of Career Development, Vol. 35 No. 2, pp. 151-165.

Wilton, N. (2012), "The impact of work placements on skills development and career outcomes for business and management graduates", Studies in Higher Education, Vol. 37 No. 5, pp. 603-620.

Zehr, S. M. and Korte, R. (2020), "Student internship experiences: learning about the workplace", Education + Training, Vol. 62 No. 3, pp. 311-324.

Zumrah, A. R. and Boyle, S. (2015), “The effects of perceived organizational support and job satisfaction on transfer of training", Personnel Review, Vol. 44 No. 2, pp. 236-254. 
Table 1

Means, Standard Deviations, and Correlations of Measures

\begin{tabular}{llrrrrrrrrr}
\hline & $n$ & $M$ & $S D$ & 1 & 2 & 3 & 4 & 5 & 6 \\
\hline 1 & Evaluation of internship (Time 1) & 77 & 7.98 & 2.27 & - & & & & \\
2 & Evaluation of internship (Time 2) & 78 & 7.85 & 2.18 & $.73^{* *}-$ & & \\
3 & Career entry worries (Time 1) & 80 & 3.39 & 1.12 & -.12 & .10 & - & \\
4 & Career entry worries (Time 2) & 80 & 3.24 & 1.06 & -.13 & -.07 & $.75^{* *}-$ & \\
5 & Employability (Time 1) & 80 & 3.47 & 0.57 & .19 & .11 & $-.58^{* *}-.53^{* *}-$ \\
6 & Employability (Time 2) & 80 & 3.54 & 0.73 & $.28^{*}$ & $.23^{*}$ & $-.49^{* *}-.60^{* *} .64^{* *}-$ \\
\hline
\end{tabular}

Note. Pearson's correlations with listwise deletion of missing values; ${ }^{*} p<.05 ;{ }^{* *} p<.01$. 
Table 2

Regression Coefficients of Evaluation of Internship on Career Entry Worries at Time 2

\begin{tabular}{lllllll}
\hline \multicolumn{1}{c}{ Variable } & \multicolumn{3}{c}{ Model 1a } & \multicolumn{3}{c}{ Model 1b } \\
\cline { 2 - 8 } & \multicolumn{1}{c}{$B$} & $\beta$ & $S E$ & $B$ & $\beta$ & $S E$ \\
\hline Constant & $0.93^{*}$ & & 0.46 & $1.04^{*}$ & & 0.44 \\
Career entry worries (Time 1) & $0.70^{* *}$ & 0.75 & 0.08 & $0.76^{* *}$ & 0.81 & 0.08 \\
Evaluation of internship (Time 1) & -0.00 & -0.01 & 0.04 & 0.10 & 0.21 & 0.06 \\
Evaluation of internship (Time 2) & & & & $-0.14^{*}$ & -0.29 & 0.06 \\
$R^{2}$ & 0.56 & & & 0.60 & & \\
$\Delta R^{2}$ & & & & $0.04^{*}$ & & \\
\hline
\end{tabular}

Note. $N=69 .{ }^{*} p<.05 ;{ }^{* *} p<.01$. 
Table 3

Regression Coefficients of Evaluation of Internship and Career Entry Worries on Employability at Time 2

\begin{tabular}{llllllllllll}
\hline \multirow{2}{*}{ Variable } & \multicolumn{3}{c}{ Model 2a } & \multicolumn{3}{c}{ Model 2b } & \multicolumn{3}{c}{ Model 2c } \\
\cline { 2 - 10 } & $B$ & $\beta$ & $S E$ & $B$ & $\beta$ & $S E$ & $B$ & $\beta$ & $S E$ \\
\hline Constant & 1.09 & & 0.65 & 1.18 & & 0.65 & $1.66^{*}$ & & 0.65 \\
Employability (Time 1) & $0.71^{* *}$ & 0.55 & 0.14 & $0.67^{* *}$ & 0.53 & 0.14 & $0.61^{* *}$ & 0.48 & 0.14 \\
Evaluation of internship (Time 1) & 0.04 & 0.12 & 0.03 & -0.00 & -0.01 & 0.04 & 0.02 & 0.06 & 0.04 \\
Career entry worries (Time 1) & -0.10 & -0.16 & 0.07 & -0.13 & -0.21 & 0.07 & 0.03 & 0.04 & 0.09 \\
Evaluation of internship (Time 2) & & & & 0.06 & 0.18 & 0.04 & 0.03 & 0.09 & 0.04 \\
Career entry worries (Time 2) & & & & & & & $-0.23^{*}-0.34$ & 0.09 \\
$R^{2}$ & 0.49 & & & 0.50 & & & 0.55 & & \\
$\Delta R^{2}$ & & & & 0.02 & & & $0.04^{*}$ & & \\
\hline
\end{tabular}

Note. $N=69 ;{ }^{*} p<.05 ;{ }^{* *} p<.01$. 


\begin{abstract}
Purpose: This study illuminates the assumption that internships facilitate the labor market entry and answers the question of why internships have a positive effect on students' self-perceived employability. It is assumed that internships enable more positive employability perceptions by reducing career-entry worries - the worries of not finding a suitable job or not being able to attainobtain a satisfactory career.
\end{abstract}

Design/methodology/approach: A two-wave study among graduate students currently in an internship investigated these relationships. Data on career-entry worries, perceived employability and thean evaluation of the internship were collected from 80 students (mean age: 24.6 years, $68 \%$ female) from various fields of study aiming at both Bachelor's and Master's degrees.

Findings: The results showed that positively-evaluated internships contributed to graduates' self-perceived employability by means of reduced career-entry worries over an eight week period.

Originality: By considering graduates' career-entry worries - the perceived uncertainty about finding an 'appropriate' career in the future - the authors introduce a new concept to the eareer'scareer literature and show that these worries are significant in terms of self-assessed employability.

Keywords: career-entry worries, employability, graduate students, work experience, internship 


\section{Perceived Quality of Internships and Employability Perceptions:}

\section{The Mediating Role of Career-Entry Worries}

Finding entryStarting out into a career as a university graduate is getting increasingly difficult, not only due to the looming economic crisis (Reidy, 2020), but also-due to ambitious expectations that employers place on applicants (Cappelli, 2012). According to the International Labour Organization's World Employment and Social Outlook, higher education alone no longer works as a guarantee for a good job, let alone as a protector against unemployment (International Labour Organization, 2017). What has been claimed to be effective for successful career entry into the labor market and abeneficial for further career development, is work experience - on top of a degree education... Indeed, one key finding from a survey among graduate employers in the UK was that graduates without previous work experience would have "little or no chance of receiving a job offer" (High Fliers Research, 2017, p. 24). This is echoed by employers and the experience of students in other countries (AlmaDiploma, 2020; Groll, 2018; Van der Werff, \& and Bisschop, 2016). Accordingly, research on students who gained work experience during their study ${ }_{2}$ confirms its positive effects on students' marketability (Gault, Leach \& Duey, 2010), speed of finding employment (Callanan \&and Benzing, 2004) and starting salary (Reddy \&and Moores, 2012) postulating a direct), which seems to confirm the link between work experience and employability.

Yet, despite a considerable volume of empirical studies on the effect of placements, internships or work experience on graduates’ employability (Brooks \&and Youngson, 2016; Mason,Williams, \& Cranmer, et al., 2009; Taylor \&and Hooley, 2014), theoretical frameworks that account for the intervening psychological processes are rare. Most studies focus on the knowledge, skills and ability fromgained from work experience (Green $\&$ and Farazmand, 2012; Messer, 2018; Wilton, 2012). Others propose that placements boost specific forms of self-efficacy (Bates, Thompson, \& Bates, et al., 2013; Lucas, Cooper, Ward, \& Cave, et al., 2009). However, work experience (or internships or placements) is not only 
helpful because it adds knowledge, skills and abilities $\dot{\bar{j}}_{2}$ its beneficial effecteffects might also result fromconsist of alleviating concerns, insecurities and worries about the future. This study will highlight thisthe particular factor that is-issue of career-entry worries which are referred to within the career literature, but hashave not yet been formally considered in explaining the positive effect of work experience: career-entry worries.. We define careerentry worries as the perceived-uncertainty of students about finding into an appropriatebeing able to successfully establish themselves professionally after graduation and thus laying the foundations for a successful career-., Career-entry worries reflectindicate that careers are perceived as far from secure by the average-university graduategraduates, despite having, on average, better job conditions and lower unemployment rates than people without degrees. They constitute a real, everyday concern for graduates (e.g., Page, 2014).

The present study thus highlights an overlooked aspect of the beneficial effects of internships on employability perceptions: the role of career-entry worries. By giving attention to career-entry worries, we expand current discussions on the beneficial effects of students' internship experiences when predicting future employment outcomes. We propose that careerentry worries play a central role in students' perceptions of their labor market skills, but that internships can reduce these. Indeed, students could purposely do an internship to reduce their insecurities and career worries. According to the career-resources model (Hirschi, 2012), work experience can be understood as enhancing human, social as well as psychological capital, which in turn drives perceived employability. The current study proposes that work experience not only enhances skills, knowledge ${ }_{2}$ and networks, but also reduces career-entry worries and thereby enhances employability perceptions. We thereby build on earlier findings on the relationship between work experience and employability, which were ambiguous (Wilton, 2012). We additionally propose that internships need to have specific characteristics to reduce career-entry worries and to positively affect employability perceptions for subsequent careers. The focus will thus be on the internship's quality and how much it 
actually promotes employability (see Pan, Gua, Wu, Han, Zhu, Fu, \& Yu, et al., 2018). From a cognitive point of view, a positive evaluation of the learning outcomes during an internship will inform students' awareness of possessing the right skills for the labor market and of being prepared for a future career, and that this eonflicts withreduces acute career-entry worries.

Our contribution to the literature thus is twofold: First, we intend to confirm that internships unleash their beneficial effects on graduates' perceived employability only if they are positively-_evaluated. Second, by introducing career-entry worries, we not only shine a spotlight onteidentify a very real, yet overlooked, subjectissue, but we also illustrate a potential mechanism to better comprehend the positive effects of internships-...

\section{A Predictor of Employability Perceptions: Graduates' Career-entryEntry Worries}

We propose that career-entry worries play a central role in how students perceive their employability. Although people's careers are multi-faceted and dynamic and there are subjective ideas about what makes a good career change over the course of a persen'sperson's working life (e.g., Jung \&and Takeuchi, 2018), the idea of 'landing'students are still concerned about starting their careers with the wrong employer, job, or occupation, is of concern to students_(Kelly \&and Lee, 2002; Stead \&and Watson, 1993).

The worryconcern of not finding appropriate employment after graduation is what we define as career-entry worries. The term 'appropriate' refers to a job that matches graduates' skills, degree, and financial needs. This specific type of fear is widely reported in careercounseling practice (e.g., Page, 2014) and seems not unfounded in today's unpredictable labor market, where graduates are often found to be under-employed (Nabi, 2003). Particularly in contexts where students accruestudying comes at a high eosts during their studies(financial) $\underline{\text { cost, }}$ there is an expectation that an appropriate career would make ithose sacrifices worthwhile.

Conceptually, career-entry worries describe the future-directed affective and cognitive estimationsapprehension that the start of not finding a way into a good career- Similar to will 
fail, and that one will not find a suitable job. Like the more general concept of careerconcerns (Creed,Fallon, \& Hood, et al., 2009), career-entry worries are characterized by the persistent apprehension of a negative future and contain a considerable uncertainty component. This apprehension is a key element of stress: “... not knowing whether an event is going to occur can lead to a long, drawn-out process of appraisal and re-appraisal, generating conflicting thoughts, feelings and behaviors [...]" (Lazarus \&and Folkman, 1984, p. 92). In fact, starting a career is a highly meaningful event, constituting one of the normative developmental tasks young people are expected to achieve in industrialisedindustrialized societies (Heckhausen, Wroseh, \& Schulz, et al., 2010), which would make a potential failure even more stressful (Lazarus \& and Folkman, 1984). This apprehension atof a potentially negative work-related future renders career-entry worries similar to other future-directed worries at work, such as the fear of becoming unemployed during times of job insecurity (De Witte, 1999), or retirement anxiety (Macewen, Barling, Kelloway \& Higginbottom, et al., 1995).

Career-entry worries are important to look at because they influence how people feel, think and approach their future careers. According to the affect-as-information hypothesis (Clore,Gasper, \& Gavin, et al., 2001), worries can serve a mental informative purpose themselves, actingand used as a heuristic when estimating the likelihood of future events. Furthermore, worries about threatening events (such as under-employment), can undermine creativity and innovation, according to the threat-rigidity hypothesis (Staw, Sandelands \& Dutton, et al., 1981; Van Hootegem, Niesen \& De Witte, et al., 2019). This is particularly detrimental to graduate students, who are encouragedrequired to have confidence in their future capabilities and think creatively about the opportunities ofshow creativity when finding a job. In that regard ${ }_{2}$ we expect that worry about career-entry leads people to rate-be more pessimistic about their own employability - which is defined as the belief of possessing 
personal characteristics, experiences and skills which are important in the labor market (Gunawan,Creed, \& Glendon, et al., 2019) - lower.

\section{Graduates' Career-Entry Worries: The Contribution of High-Quality Internships}

Having established that career-entry worries are likely to play a decisive role in predicting employability, the question is what can be done to reduce them. One way to reduce uncertainty is by regainingto regain control. Gaining workWork experience in the form of an internship is a great way of regaining control over an uncertain future career, for several reasons.

Firstly, the process of applying for an internship provides training in the application process for the desired field of work, and teaches about the qualifications and social skills that employing organizations wantlook for (Liu,Huang, \& Wang, et al., 2014). This information replaces rather vague ideas with clear experience (Kapareliotis, Voutsina, \& Patsiotis, et al., 2019) and so reduces uncertainties surrounding labor market entry. Secondly, the work experience itself provides graduates with a realistic job-preview of work after graduation (Rose, 2018; Zehr \&and Korte, 2020) and could be understood as a trial-run transition (Inceoglu,Selenke, MacDowall, \& Schlachter, et al., 2019). Thereby, the prospect of working in a professional context becomes less unknown and less of a threat. Finally, any work experience can be understood as an opportunity to broaden a person's skills, knowledge and repertoire of problem-solving strategies (Brooks, Cornelius, Greenfield, \& Joseph, et al.,1995; Inceoglu et al.,2019; Jones, Mardis, McClure, Ma, Ambavarapu, \& Spears, et al., 2017). Any challenge and task that is successfully mastered strengthens the belief that one will be able to handle oneself in professional surroundings, which fosters the appraisal of coping abilities and skills for future job challenges (Bandura, 1982).

Yet, internships vary in their quality and not all types of work experience might calm graduates' career-entry worries- to an equal degree. The quality of an internship is assumed to predictwill play a crucial role for individuals' career-entry worries for several reasons. When 
graduates evaluate whether an internship is more or less-suitable-to prepare for their subsequent career, they will, first, consider their satisfaction with it. According to the welldocumented relationship between satisfaction and performance (Judge, Thøresen, Bønø, \& Patton, et al., 2001), students who have a rather satisfying work experience will not only show better performance in their job, but will also transfer the learning content to their daily lives better (e.g., Jodlbauer Selenke, Batinic, \& Stiglbauer, et al., 2011). A satisfying internship that gives graduates more confidence in knowing what they cantheir abilities, will thus interfere withreduce potential negative feelings, such as career-entry worries, and reduce the uncertainty and anxiety associated with it. Secondly, when establishing the quality of a placement, graduates willalso evaluate thetheir learning outeome of their internship. Theoutcomes which in turn will impact their career-worries: the degree to which graduates perceive their internship as a source of skill, ability and knowledge gain will shape their estimation of being qualified for a subsequent job and, hence, their perceptions efon finding an adequate job. Finally, in order to deliver clarity on the subsequent labor market entry and to reduce uncertainty and worries, the internship needs to be perceived as useful for the prospective job. If students evaluate their internship as useful for their future career, it eentributeswill also contribute to the reduction of career-entry worries.

However, a $\underline{A}$ high-quality internship that contributes to graduates' evaluation of possessing the 'right skills' for the labor market, will not only reduce career-entry worries but also directly influence their employability perceptions. There is a significant amount of research on the positive relationship of internships on students' employability perceptions. For example, Jackson (2013) surveyed a sample of students completing work placements, internships and work experiences and shoufound that students reported a significant increase in perceived employability skills such sselfas self-management in the workplace or problem-solving skills. Likewise, work placements were demonstrated to have significant 
value-added effects on employability skills, such as the ability to work in teams, selfconfidence, or leadership (Wilton, 2012; Messer, 2018).

Essentially, graduates' employability perceptions comprise two things: the estimation of their chances in the labor market due to the degree program and the university they are enrolled in, and their self-perceived value in the job market, due to skills and other personal attributes (Rothwell,Herbert, \& Rothwell, et al., 2008). Particularly the The latter estimation might be particularly strongly influenced by work experience: Itit is likely to undergo a profound change during an internship (Salancik \& and Pfeffer, 1978). During their internships, graduates will get feedback on their skills and competencies, either formally or on a day-today basis. Also, they will learn about adequate qualifications and necessary skills in a desired field of work (Zehr \&and Korte, 2020). Finally, their perspective of being able to address challenges at work in the future due to personal attributes and abilities, will change by successfully accomplishing work assignments during their internship, which isare all supposed to foster graduates' perception of the social and human capital they possess, their confidence in their skills and, hence, their belief in being employable (Bandura, 1977; Rothwell et al., 2008).

\section{High-Quality Internships: Considering Confounding Variables}

Based on literature on learning and training transfer and internship outcome research, we postulated that career-entry worries might erode the perception that one is employable, while high-quality internships reduce the fear that one might not find an adequate entry into the labor marketwill not succeed. Yet, there are several features of the organization, such as the organizational climate, its culture, or the fit between the employee and the organization, which will additionally influence the evaluation of training and learning experiences (Zumrah $\&$ and Boyle, 2015). We thus have to-consider these factors as confounding variables in order to make statements about the benefits thatthe relationship between high-quality internships have $\mathrm{on}_{2}$ career-entry worries and employability. 


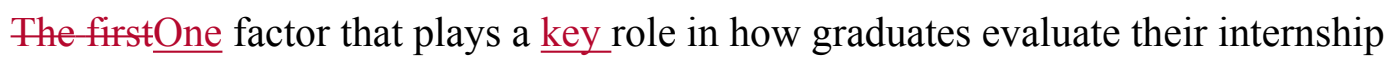
quality is positive affect. Considering positive affect (e.g. feeling energetic, excited, cheerful) as a confounding variable is important for at least two reasons. First, we assume that the The affective experiences of graduates during the internship directly affect the evaluation of their internships. For example, the experience of grumpy colleagues and lonely lunches will likely make trainees feel uncomfortable or feel-unhappy, probably leading to a more critical evaluation of the internship (cf. Burke \&and Hutchins, 2007) - and vice versa, positive affective states during the internship might lead to an over-estimation of the internship's quality. The second reason is based on findings thatFurthermore, affective states have been

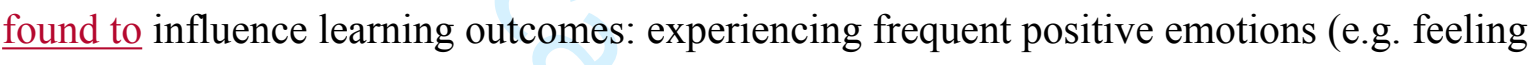
enthusiastic and cheerful or feeling calm) is likelyassumed to broaden attention and eognition and-make learners more receptive towardto new experiences (Fredrickson, 2004; Reschly, Huebner, Appleton, \& Antaramian, et al., 2008). Thus, positive affect can lead to better knowledge-gain during the internship and not controlling for positive affect might contribute to an over-estimation of the learning experience during the internship.

The second variable we consider in controlling the effects of internships' quality on eareer-entry worries and employability perceptionsas confounding variable is perceived person-environment fit. The evaluation of how much-an organization provides individuals with opportunities to gain new knowledge, for example through high quality internships,internship will be affected by how individuals perceive their fit with the organization (Betz \&and Judge, 1994; Awoniyi,Griego, \& Morgan, et al., 2002)): the more people feel they 'fit', the more they will see opportunities to learn and persongrow. Personenvironment fit perceptions might thus influence graduates' feelings of being prepared for their labor market entry which is confirmed by relevant literature: for example, Indeed, research shows that the misfit between the demands people encounter at work and their abilities has been related to increased stress perceptions in organizational research(Edwards, 
1996) and, similarly). Similarly, we-might expect that students who perceive a mismatch between the demands of their internship and their abilities will experience a surge in careerentry worries-

Our illustrations of associations between how graduates evaluate their internship and its effects on their career-entry worries and self perceived employability respectively, over and aboveThe inclusion of affective experiences and perceptions of person-environment fit are summarized in aas boundary factors leads to the first hypothesis:::

Hypothesis 1: Internships that are positively-evaluated reduce career-entry worries (Hypothesis 1a) and increase employability perceptions (Hypothesis 1b) over and above positive affective states and person-environment fit.

\section{The Indirect Effect of High-Quality Internships on Perceived Employability via Career- Entry Worries}

We not only propose that high-quality internships will directly influence career-entry worries and employability, but we also presume an indirect effect: high quality internships will reduce career-entry worries, and thereby enhance employability perceptions.

The literature provides some support for this assumption. For example, De Cuyper and colleagues (2008) suggest that job insecurity - the worry of losing one's job (Mauno, Leskinen, \& Kinnunen, et al., 2001) - plays a mediatory role in the affective well-being and employability relationship. To the degree that job insecurity and career-entry worries are comparable (as they are both future-oriented employment worries with a high uncertainty component) this might suggest that career-entry worries act as an explanatory factor in the relationship between internship quality and employability. Comparing the insecurity of employees about maintaining a job (job insecurity), with the concerns of graduating students about not finding an appropriate job after their studies (career-entry worries), Spurk and colleagues (2016) also demonstrate a mediating mechanism which explains the effects of positive career experiences in the context of employability perceptions. Further, as one 
possible route to employability, Van Emmerik and colleagues (2012) suggested that an individual's perception of job opportunities mediates the link between job resources and employability, and we propose that a person who perceives a lot of job opportunities is also less worried about entering a career. Finally, Alisic and Wiese (2020) recently found that doing an internship (which they would refer to as work-related self-management behavior) decreases perceived career insecurity via increases in positive perception of one's future development. This lends support for our hypothesis that career-entry worries act as an inhibitor to developing positive employability perceptions, particularly when comparing career insecurity as a 'feeling of powerlessness' to maintaining continuous employability (Colakoglu, 2011, p. 50) and the fear of not reaching career goals (Höge,Brucculeri, \& Iwanowa, et al., 2012) with career-entry worries as the fear of not finding an appropriate career after graduation.

In this way, career-entry worries are likely to function as the connecting bridge between internship experiences and employability perceptions. To test this assumption more explicitly we postulate a second hypothesis:

Hypothesis 2: The effect of positively-evaluated internships on graduates' selfperceived employability will be mediated by career-entry worries.

\section{Method}

\section{Procedure and Study Design}

The study targeted students who were engaged in an internship at the time of the-data collection. They were approached by emaile-mail invitations which were sent to universities, companies and labor unions in Germany and Switzerland, posts in relevant newsgroups of professional online networks, and announcements in social networks, online communities dedicated to career interventions and universities' career service trainee networks. According teln line with the requirements of the ethics committee of the department where the study was carried out, the study took into account any relevant legal provisions, in particular with regard 
to data protection, and additional measures were taken to minimize the risks to which respondents may have been exposed. Specifically, the online data collection did not proceed without respondents' explicit consent to an ethics note (regarding, for example, anonymity, voluntariness ${ }_{2}$ and data protection issues). There was no incentive for participation in the study.

In accordance with requirements of numerous study programs in Germany, which stipulate the compulsory completion of a, at least, a six-week internship-as compulsory in order to acquire practical knowledge (internships that are not a compulsory part of one's studies usually also span a period of six to eight weeks), the survey period was precisely defined: Measurement point 1 was set at the first week of the winter term's semester break, measurement point 2 was scheduled eight weeks later, to ensure that students in the sample had spent a sufficient amount of time in the internship and were able to judge their work experience realistically. Career-entry worries, perceived employability and the evaluation of the internship were assessed at both measurement points of the study. The control variables were assessed once.

\section{Sample}

80 students participated in our study at both measurement points. They were between 20 - 40 years old $(M=24.59, S D=3.25)$. Most of the participants were female $(68 \%)$. Participants were enrolled in the German higher education system. 51.3\% of the participants aimed for a -Bachelor's degree, 45.0\% a Master's degree, and 3.7\% atother degrees,_such as state examinationexaminations. The average number of semesters was 5.44 for Bachelor students $(S D=2.20)$ and 3.42 for Masters students $(S D=1.56)$. The sample comprised students enrolled in law and business schools (62.5\%), arts and humanities (12.5\%), engineering (8.8\%), mathematics and the natural sciences (6.3\%), med school and health sciences $(2.3 \%)$ and other fields of studies (7.5\%). The majority was enrolled in universities $(82.5 \%)$ and $17.5 \%$ were enrolled in universities of applied sciences. 
On average, the respondents had earned 98.61 ECTS points $(S D=55.13)$, with an average grade of 1.93 in the German system $(S D=0.51)$, which ranges from 1 (very good/ outstanding achievement) to 5 (not sufficient / failed). The majority conducted their internship in their home country, Germany (except four students from other German-speaking countries), $3.8 \%$ of the sample had moved abroad temporarily for their internship.

\section{Measures}

\section{Evaluation of the internship.}

Students' appraisal of their internship was assessed using the Questionnaire for Professional Training Evaluation (Q4TE; Grohmann \&and Kauffeld, 2013), a widely-used measure within thein recent training and transfer literature with German-speaking samples (e.g., Massenberg, Spurk, \& Kauffeld, et al., 2015; Diethert, Weisweiler, Frey, \& Kerschreiter, et al., 2015). We used three of its subscales, assessing participants' overall satisfaction with the internship, amount of skills and knowledge that they required in their internship, and a rating of its overall utility for the future, on an 11-point scale, ranging from $0 \%$ (completely disagree) to $100 \%$ (completely agree). As indicated by the scale authors, these three two-item subscales form a compound short-term evaluation measure (Grohmann $\&$ and Kauffeld, 2013). To fit the context, the six items of the original scale were rephrased, with the word 'training' being replaced by 'internship, and 'work' by 'study' (e.g. 'I will keep the internship in good memory." or "I learned a lot of new things in the internship."). The reliability of the scale was good with Cronbach Alpha's of .87 (Time 1) and .88 (Time 2).

Career-entry worries. Career-entry worries were assessed with items that lean on Borg's (1992) and Borg and Elizur's (1992) conception of job insecurity. The original job insecurity items assess the worries that individuals experience about losing their job and estimations about the likelihood of keeping their job. To consistently adapt this measure, we took the 10-item German version of Borg's (1992) scale and replaced (1) any expression concerning "losing a job" with the expression "not finding a suitable job" and (2) the 
expression "likelihood of keeping a job" with the expression "likelihood of getting a suitable job”. Thereby, the term 'suitable' was important, as probably every student could find employment in an under-qualified profession. Two items from the original scale ("I look forward with confidence to the introduction of new technologies." and "I clearly know my chances for advancement in the coming years.”) were not deemed appropriate for the situation of graduate students and were not transferred. This resulted in a scale consisting of eight items, to which respondents had to indicate their agreement or disagreement on a 7-point Likert scale. The items of this scale were recodedre-coded, so that high values indicated high career-entry worries. Example items are "The thought of not finding a suitable career-entry worries me.” or "The prospect of not finding a suitable job concerns me.”. The internal reliability of the career-entry worries scale was good, both at Time $1(\alpha=.90)$ and Time $2(\alpha$ $=.91)$.

Self-perceived employability. To assess self-perceived employability, we used a shortened version of the Self-Perceived Employability Scale for students (Rothwell et al., 2008) in a German translation. In particular, we used four items from the internal employability subscale. This subscale assesses respondents' estimation of their internal employability attributes, such as skills and abilities, using a 5-point Likert-style scale from 1 (strongly disagree) to 5 (strongly agree). Example items are: "The skills and abilities that I possess are what employers are looking for." and "I feel I could get any job so long as my as my skills and experience are reasonably relevant.". The internal consistency of the internal employability scale was acceptable at both measurement points $\left(\alpha_{\mathrm{T} 1}=.61\right.$ and $\left.\alpha_{\mathrm{T} 2}=.70\right)$.

Control variables. The following aspects were assessed as covariates: affective states during the internship and person-environment fit. As additional control variables, we considered gender and age, GPA, number of previous internships and the number of credits earned during studies. 
Affective states during the internship were assessed with a German translation of the Multi-Affect Indicator by Warr and colleagues (Warr,Bind1, Parker, \& Inceoglu, et al., 2014). The Multi-Affect Indicator measures job-related affects considering the level of activation (high - low) and the affective valence (positive - negative). In the present study, positive

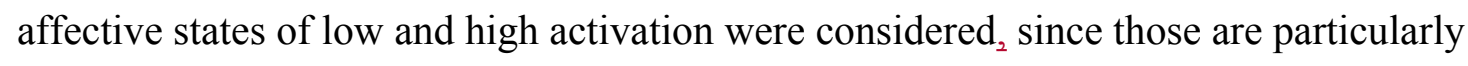
important in the work context and adequately fit the state of high energy and activity during internships. Participants had to indicate how frequently they experienced four high-activation pleasant affective states (e.g. feeling enthusiastic) and four low-activation pleasant affective states (e.g. feeling comfortable) during the previous week of their internship, on a 7-point scale ranging from 1 (never) to 7 (always). The assessment of participants' affective states took place at Time 2 , to control for the potentially confounding effect on the evaluation of the internship at Time 2 , since research shows that students evaluate their internship experience significantly more positively than they would have expected at the beginning of their internship (Neelam et al., 2019). Cronbach's Alpha in the present study confirmed moderately satisfactory internal consistencies of subscales with .58 (high activation positive affect) and .86 (low activation positive affect), which is comparable to the reliabilities found by the scale's authors, indicating an accurate translation which was well-adapted to the German language.

Person-environment fit comprises the facets of Person-organization fit, Needs-supplies fit, and Demands-abilities fit, which were assessed with a validated German translation of Cable and DeRue's (2002) measures of perceived fit at work (Haustein, 2016). Fit perceptions were measured on a 5-point scale ${ }_{2}$ ranging from 1 (to a very little extent) to 5 (to a very large extent). Respondents were asked to rate their agreement to nine items (three for each subscale) by thinking of the organization they worked for and their everyday experiences in the respective organization. A sample item is "The things that I value in life are very similar to the things that my organization values." (person-organization fit; item derived from the 
original English scale). Within the study sample, the subscales of this widely-used measure showed good reliability with .96 (person-organization fit), .91 (needs-supplies fit), and .87 (demands-abilities fit), which equal the consistencies above .80 of the original English version (Cable \& and DeRue, 2002). We controlled the potential confounding effect of personenvironment fit perceptions on the evaluation of the internship at Time 1, considering previous findings that perceptions of fit measured at organizational entry are not stable but grow through socialization processes within the employing organization (De Cooman et al., 2009; Cooper-Thomas, van Vianen, \& Anderson, et al., 2004).

\section{Statistical Analyses}

Analyses were conducted using R 3.6.1 (R Core Team, 2019). We first conducted a hierarchical regression analysis predicting career-entry worries at Time 2 while controlling for career-entry worries at Time 1 . This approach controls for between-subject effects of careerentry worries at the beginning of the internship and, accordingly, the regressions predict the change in career-entry worries throughout the internship; the same procedure was applied to perceived employability. The predictors were included separately for both measurement times in the regressions. For example, in predicting employability, the effect of career-entry worries at Time 1 represents the baseline measurement, while the effect at Time 2 indicates the influence of the change in career-entry worries since Time 1 on the change of employability at Time 2 . For testing the hypotheses, the effect of career-entry worries at the second measurement time is particularly important, since this predictor represents a within-subject effect and allows first conclusions to be drawn about the causality relationships (cf. Cohen, Cohen, West, \& Aiken, et al., 2003).

\section{Results}

\section{Preliminary Analyses}

We conducted preliminary analyses in orderanalysis to decide whether or not to include the control variables, as described in the methods section. We considered gender and age, 
GPA, number of previous internships and the number of credits earned during studies as control variables. We also included possible confounds as covariates, namely positive affective states and person-environment fit. Since the control and the confounding variables had no influence and there was no substantial difference in the analyses'analysis' results with and without these variables, we conducted the main statistical analysesanalysis without control (e.g. gender, age) and confounding variables (affective states and person-environment fit).

\section{Correlations of Measures}

First, an inspection of the Pearson correlations of the variables in the study was carried out (Table 1). The evaluation of the internship at Time 1 was not correlated with career-entry worries at Time $1, r=-.12, p=.300$, and perceived employability at Time $1, r=.19, p=.100$, but was positively associated with perceived employability at Time $2, r=.28, p=.016$. Also, the evaluation of the internship at Time 2 was associated with perceived employability at Time $2, r=.23, p=.046$. As expected, career-entry worries were negatively correlated with employability both at Time $1, r=-.58, p<.001$, and at Time $2, r=-.60, p<.001$.

Insert Table 1 about here

\section{The Effects of Internships on Career-Entry Worries and Perceived Employability}

Hypothesis 1 states that positively-evaluated internships reduce career-entry worries (Hypothesis 1a) and enhance self-perceived employability (Hypothesis 1b). In order to test Hypothesis 1a, we conducted a hierarchical regression analysis predicting career-entry worries at Time 2 (Table 2). In Model 1a, we included career-entry worries at Time 1 as well as evaluation of internship quality at Time 1 . Since we regressed career-entry worries at Time 2 on career-entry worries at Time 1, we predicted the change in career-entry worries in the eourse ofduring the internship. As might be expected, career-entry worries at Time 1 
predicted career-entry worries at Time $2, b=0.70, p<.001$. The evaluation of internship quality at Time 1 had no influence on the change in career-entry worries, $b=-0.00, p=.945$. In Model 1b, we included the evaluation of internship quality for Time 2 . Since Time 1 constitutes a baseline measurement, we were especially interested in the effect of the internship quality at Time 2, which indicates the change of the evaluation in the course of the internship. Model $1 \mathrm{~b}$ indicates that the evaluation of the internship at Time 2 is negatively related to career-entry worries, $b=-0.14, p=.015$. Thus, an increase in the evaluation of the internship, results in a decrease efin career-entry worries, which supports Hypothesis 1a.

Insert Table 2 about here

Table 3 outlines the results of hierarchical regression analyses predicting self-perceived employability. Again, we regressed employability at Time 2 on employability at Time 1, thus, predicting the change in employability in the course of the internship. Model 2a included employability, evaluation of internship quality, and career entry worries at Time 1.

Employability at Time 1 was revealed as significant, $b=0.71, p<.001$, indicating the temporal stability of perceived employability. In Model 2b, we additionally included the evaluation of the internship. The results indicated that internship quality at Time 2 did not contribute to a higher perceived employability at Time $2, b=0.06, p=.173$. Thus, Hypothesis 1b was not supported.

Insert Table 3 about here 


\section{The Indirect Effect of Internship Quality on Perceived Employability via Career-Entry Worries}

Hypothesis 2 states that a positive evaluation of an internship will reduce career-entry worries, which, in turn, increases employability perceptions over and above positive affective states and person-environment fit. In Model 2c, we extended the analysesanalysis by including career-entry worries at Time 2 , which contributes to the model fit, $\Delta R^{2}=0.04, p=$ .015 . The negative influence of career-entry worries on employability at Time $2, b=-0.23, p$ $=.015$, indicates that lowered career-entry worries are associated with an increase in employability perceptions. To test Hypothesis 2 about the indirect effect of internship quality on perceived employability by way of career-entry worries, we conducted a causal mediation analysis following Imai, Keele and Tingley (2010). The analysis is based on Model $1 \mathrm{~b}$ and Model 2c, and thus; includes the control variables of low_- and high--activated positive affective states and three dimensions of person-environment fit, as reported in Tables 2 and 3. The results support an indirect effect, $b=0.03, p=.022, C 195[0.003 ; 0.080]$, which confirmed Hypothesis 2 (Figure 1). Overall, a positive evaluation of internship quality leads to a decrease in career-entry worries, which ${ }_{2}$ in turn ${ }_{2}$ enhances perceived employability over and above positive affective states and estimations of person-environment fit during the internship.

Insert Figure 1 about here

\section{Discussion}

“[...] for students there's one anxiety that comes back again and again: will I find a job when I graduate?" (Page, 2014). The current study set out to introduce this anxiety of graduate students as career-entry worries to the literature. We argued that graduate students who worry more about not finding the right job in the future-would estimate their 
employability lower and we presumed that career-entry worries could be reduced by positive internship experiences. Based on the literature on affect at work, training transfer, and personenvironment fit, we additionallyalso predicted that internships that allow for satisfactory and positive learning experiences, would be able to reduce career-entry worries over and above positive affect and the fit of a person's values, needs and abilities with the employing organization.

The findings of a two wave-study among graduate students in Germany and Switzerland provided substantial support for some of these assumptions. First, career-entry worries were confirmed to play an explanatory role in predicting employability perceptions over time. We found that worrying about one's labor market entry impairs employability perceptions among graduate students. Additionally, we found that career-entry worries can be moulded by work experience. More importantly, we found that it was through the reduction in career-entry worries, that positively-evaluated internships contributed to an increase in employability perceptions. Just on its own, completing a high-quality internship did not lead to higher employability perceptions. Rather, it was the reduction of career-entry worries that was eausedlinked by positively-evaluated internships which affected graduates'with improved employability perceptions. Therefore, we can make a rather strong case for the detrimentalimportant role of career-entry worries foron graduate students' employability perception and their transition into the labor market.

\section{Limitations and Future Research}

There are a number ofseveral limitations to our findings. First, the study consisted of a relatively small convenience sample of graduate students. Respondents were invited via email and newsgroups or word-of-mouth by other students. This strategy might have failed to recruit those who worried too much or too little about their future labor market entry: People who worry too much or too little might not want to mentally engage with the content of our study (catchword 'career') or might not even take up an internship. The small number of 
respondents further implies that only relatively powerful effects could be detected (Fritz \&and MacKinnon, 2007), which limits the conclusions that can be drawn. In addition, the small sample size prohibited the application of structural equation modeling (SEM) which would have been ideal for identifying the suspected relationships in the data.

Secondly, we cannot draw robust conclusions about causality. Though our analyses relied on within-subject effects while controlling for between-subject effects (Montoya, 2020), we cannot completely rule out reverse causality, in that students who were less worried weremight have been more likely to attainhave better experiences during their internships. Instead, preference should be given to study designs that allow for more robust causal conclusions, such as the study by Pan and colleagues (2018), who proposed and tested the indirect effect of interns' proactive personality on employability success by taking account of the internships' quality within a four wave-study. In contrast, the two-wave data of our study limits the conclusions that can be drawn about the proposed indirect effect; for a true test, at least three measurement points would be needed (Cole \&and Maxwell, 2003). At least the two-wave design reduces the chance that common method bias influenced our results (Podsakoff,MacKenzie, Lee, \& Podsakoff, et al., 2003). Ultimately, it would be interesting to explore the role of career-entry worries as a moderator: pronounced career-entry worries might reduce the (positive) effect that internships could have on graduates' perceived employability.

Third, the self-report nature of the data might also have affected the findings. Since employability is related to career success (e.g., De Vos, De Hauw, \& Van der Heijden, et al., 2011), it would have been interesting to include 'hard' measures of labor market entry success. There are some sound ways of measuring graduates' labor market entry success more objectively, and we encourage including information like the ratio of the number of applications for a job that were sent to employers compared to the number of positive reactions in the sense of invitations to interviews. 
Despite these limitations, we believe that our research opens a number ofseveral new avenues for future studies that might be of interest to researchers in the areas of careertransitions into work, graduate employment and newcomer socialization.

\section{Practical Implications and Conclusion}

We believe we could make a strong case that career-entry worries among graduate students need to be taken seriously by universities and by organizations offering internships. Career-entry worries influence students' employability perceptions, as this study shows, but can be reduced by high quality internships. There are several practical lessons to be learned from these findings.

First of all, the finding that career-entry worries are a relevant concern for graduate students is important in itself. We have identified and provided a measure for a potentially common stressor among students, one that seems to be particularly relevant in the wake of the worldwide pandemic. Given the strained situation on the graduate job market and also the fact that mental ill-health is on the rise in student populations, student support services might want to pay extra attention to career-entry worries when providing eounsellingcounseling support (Newman,Fuqua, \& Seaworth et al.,1989; Thorley, 2017; Wendlandt \&and Rochlen, 2008).

Secondly, the study also shows that career-entry worries can be amended: namely by providing high quality internships, which are perceived as meaningful, satisfying and as a source of skill and knowledge. This highlights how important it is that internships are wellplanned and designed to deliver the right learning outcomes (e.g., Bauer, Erdogan, Bodner, Truxillo\& Tucker, et al., 2007; McManus \&and Feinstein, 2014). The responsibility for ensuring the quality of internship lies with organizations - but also with universities, in situations where internships form part of degree programs. Employers need to recognize that they can greatly influence whether trainees feel better prepared for the labor market entry through the internships they offer (Neelam et al., 2019). Offering a high-quality internship 
can also reflect positively on organizations themselves (through social media such as @ratemyplacement) and thereby make them more attractive for future job applicants.

There is an extensive knowledge base on how to improve the quality of internships already (see e.g. Baily, Barber, \& Nelsøn, et al., 2016 for common practice and suggestions). One possibility to enhance the learning experience would be to set specific learning objectives for the internship with the trainees (in particular various aspects of procedural and declarative knowledge) and have regular conversations about them (cf. Bhattacharya \&and Neelam, 2018). Other suggestions would be to sharpen interns' awareness of their learning process, for example by encouraging the use of self-reflective work-diaries. Also, regular supervision by a member of faculty has been shown to be beneficial (Baily et $a_{\overline{5 . .2}}$ 2016).

But universities can do more to support their students in overcoming their career-entry worries, in particular by encouraging them to take responsibility for their career-entry, for example ${ }_{2}$ by prompting them to actively look out for role models and to seek information and experiences that replace non-specific concerns with factual knowledge. Universities can help establishingestablish contact with employers (e.g. through brown paper talks, lecture series, career-fairs, etc.), and help students build confidence that the search forin finding role models or opportunities to findgain adequate work experience, ${ }_{2}$ which counteractcounteracts vague worries, for example ${ }_{2}$ by integrating workshops on "career-entry" or "career design" into their curricula, where possible measures on how to proactively and effectively shape thestudents' labor market entry are presented.

In conclusion, this research stresses the importance of high-quality internships from a psychological angle: internships have significant psychological benefits, in the form of reducing graduates' career worries. Having fewer career worries is important, as it can enhance graduates' confidence of finding a successful, sustainable career. 


\section{References}

Alisic, A,\&. and Wiese, B. S. (2020).), "Keeping an insecure career under control: Thethe longitudinal interplay of career insecurity, self-management, and self-efficacy.", Journal of Vocational Behavior, Vol. 120, 103431-, available at https://doi.org/10.1016/j.jvb.2020.103431.

Awoniyi, E. A., Griego, O. V-, \&. and Morgan, G. A. (2002)-., "Person-environment fit and transfer of training.", International Journal of Training and Development, Vol. 6 - No. 17, ,pp. 25-35.

AlmaDiploma (2017)-.), “XIV Indagine Esitiesiti a distanza dei Diplomati. Rapportodiplomati. rapporto 2020 .." $\left[14^{\text {th }}\right.$ rapport on the destinations of graduate students].], Associazione di Scuole AlmaDiploma. Downloaded 10/5/2020 from, available at:

http://www.almadiploma.it/info/pdf/scuole/occupazione2019/Rapporto_2020_ESITI.pd f(accessed 10 May 2020)

Bandura, A. (1977)-.), "Self-efficacy: toward a unifying theory of behavioral change-", Psychological Review, Vol. 84(№. 2), pp. 191-215.

Bandura, A. (1982)-., "Self-efficacy mechanism in human agency:", American Psychologist, Vol. $37($ No. 2), pp. 122-147.

Bailey, S. F., Barber, L. K., \&. and Nelson, V. L. (2017)._, “Undergraduate internship supervision in psychology departments: Use $\underline{\text { use }}$ of experiential learning best practices:", Psychology Learning \& Teaching, Vol. $16(-$ No. 1), pp. 74-83.

Bauer, T. N., Bodner, T., Erdogan, B., Truxillo, D. M., \&. and Tucker, J. S. (2007)- -), “Newcomer adjustment during organizational socialization: Aa meta-analytic review of antecedents, outcomes, and methods:.”, Journal of Applied Psychology, Vol. 92(№. 3), pp. 707-721. 
Bates, M., Thompson, C., \&. and Bates, L. J. (2013)-_, "Not all dimensions of work selfefficacy are equal: Understandingunderstanding the role of tertiary work placements in the development of the elements of work self-efficacy.", Journal of Cooperative Education and Internships, Vol. 47(-No. 1), pp. 19-30.

Betz, Jr, R. D., \&. and Judge, T. A. (1994)-), "Person-organization fit and the Theory of Work Adjustment: Implicationsimplications for satisfaction, tenure, and career success.", Journal of Vocational Behavior, Vol. 44(-No. 1), , pp. 32-54.

Bhattacharya, S., \&. and Neelam, N. (2018)-), "Perceived value of internship experience: a try before you leap.", Higher Education, Skills and Work-Based Learning, Vol. 8 - No. 4), pp. 376-394.

Borg, I. (1992)-. , „Ueberlegungen und Untersuchungen zur Messung der subjektiven Unsicherheit der Arbeitsstelle:", Zeitschrift fuer Arbeits- und Organisationspsychologie, Vol. 36 No. 3,pp. 107-116.

Borg, I., \&. and Elizur, D. (1992)-.), “Job insecurity: Correlatescorrelates, moderators and measurement.", International Journal of Manpower, Vol. 13(-No. 2), pp. 13-26.

Brooks, L., Cornelius, A., Greenfield, E., \&. and Joseph, R. (1995)..), “The relation of careerrelated work or internship experiences to the career development of college seniors:", Journal of Vocational Behavior, Vol. 46(-No. 3), pp. 332-349.

Brooks, R., \&. and Youngson, P. L. (2016)-.), "Undergraduate work placements: an analysis of the effects on career progression:", Studies in Higher Education, Vol. 41(-No. 9$)$,, pp. $1563-1578$.

Burke, L. A., \&. and Hutchins, H. M. (2007)-), “Training transfer: Anan integrative literature review:", Human Resource Development Review, Vol. 6(-No. 3), pp. 263-296.

Cable, D. M-,\&. and DeRue, D. S. (2002)-), “The convergent and discriminant validity of subjective fit perceptions.”, Journal of Applied Psychology, Vol. 87(-No. 5), pp. 875884. 
Callanan, G.,\&. and Benzing, C. (2004)..), “Assessing the role of internships in the careeroriented employment of graduating college students.”, Education + Training, Vol. $46 f$ No. 2), pp. 82-89.

Cappelli, P. (2012)-., Why good people can't get jobs. The skill gap and what companies can do about it. Philadelphia, PA: ${ }_{2}$ Wharton Digital Press, Philadelphia, PA.

Clore, G. L., Gasper, K., \&. and Garvin, E. (2001)-), “Affect as information-In J. P..” Forgas, J. P. (Ed.), -Handbook of affect and social cognition (pp. 121-144). Mahwah, NJ.: Lawrence Erlbaum Associates, Mahwah, NJ, pp. 121-144.

Cohen, J., Cohen, P., West, S. G., \&. and Aiken, L. S. (2003)._, Applied multiple regression/correlation analysis for the behavioral sciences. London: ${ }_{2}$ Lawrence Erlbaum Associates, London.

Colakoglu, S. N. (2011).), “The impact of career boundarylessness on subjective career success: Thethe role of career competencies, career autonomy, and career insecurity.", Journal of Vocational Behavior, Vol. $79($ No. 1), pp. 47-59.

Cole, D. A.,\&. and Maxwell, S. E. (2003).), “Testing mediational models with longitudinal data: questions and tips in the use of structural equation modeling.", Journal of Abnormal Psychology, Vol. 112(№. 4), pp. 558-577.

Cooper-Thomas, H. D., Van Vianen, A., \&. and Anderson, N. (2004). , , "Changes in personorganization fit: Thethe impact of socialization tactics on perceived and actual P-O fit-", European Journal of Work and Organizational Psychology, Vol. 13(-No. 1), pp. $52-78$.

Creed, P. A., Fallon, T.,\&. and Hood, M. (2009)-.), "The relationship between career adaptability, person and situation variables, and career concerns in young adults: “, Journal of Vocational Behavior, Vol. 74( No. 2), pp. 219-229. 
De Cuyper, N., Bernhard-Oettel, C., Berntson, E., De Witte, H., \&. and Alarco, B. (2008)-_, “Employability and employees' well-being: Mediationmediation by job insecurity:", Applied Psychology, Vol. 57(-No. 3), pp. 488-509.

De Cooman, R., De Gieter, S., Pepermans, R., Hermans, S., Du Bois, C., Caers, R., \&. and Jegers, M. (2009)-.), "Person-organization fit: Testingtesting socialization and attraction-selection-attrition hypotheses:", Journal of Vocational Behavior, Vol. 74( No. 1), pp. 102-107.

De Vos, A., De Hauw, S., \&. and Van der Heijden, B. I. (2011)-. „ب “Competency development and career success: Thethe mediating role of employability"., Journal of Vocational Behavior, Vol. $79($ No. 2), pp. 438-447.

De Witte, H. (1999)-.), “Job insecurity and psychological well-being: Reviewreview of the literature and exploration of some unresolved issues.", European Journal of Work and Organizational Psychology, Vol. 8(- No. 2), pp. 155-177.

Diethert, A. P., Weisweiler, S., Frey, D., \&. and Kerschreiter, R. (2015)-.), “Training motivation of employees in academia: developing and testing a model based on the theory of reasoned action,", Zeitschrift für Erziehungswissenschaft, Vol. 18(№. 1), pp. 29-50.

Edwards, J. R. (1996)-_, “An examination of competing versions of the person-environment fit approach to stress:-, Academy of Management Journal, Vol. 39(№. 2), pp. 292339.

Fornell, C., \&. and Larcker, D. F. (1981)-.), "Evaluating structural equation models with unobservable variables and measurement error:", Journal of Marketing Research, $\underline{\text { Vol. }}$ 18 No. 1, pp. 39-50.

Fredrickson, B. L. (2004).), "The broaden-and-build theory of positive emotions:", Philosophical Transactions of the Royal Society B: Biological Sciences, Vol. $359+\underline{-N o .}$ 1449),, pp. 1367-1377. 
Fritz, M. S.,\&. and MacKinnon, D. P. (2007)._, "Required sample size to detect the mediated effect.", Psychological Science, Vol. 18(-No. 3), pp. 233-239.

Gault, J., Leach, E., \&. and Duey, M. (2010).), “Effects of business internships on job marketability: the employers' perspective.", Education + Training, Vol. 52(-No. 1), pp. 76-88.

Green, R. D., \&. and Farazmand, F. A. (2012)-), "Experiential learning: Thethe internship and live-case study relationship:", Business Education \& Accreditation, Vol. 4(№. 1), pp. 13-23.

Grohmann, A-, \&.. and Kauffeld, S. (2013)-_, "Evaluating training programs:

Developmentdevelopment and correlates of the questionnaire for professional training evaluation:", International Journal of Training and Development, Vol. 17(-No. 2), pp. 135-155.

Groll, T. (2018)-. „, Kein Job ohne Praktikum. Retrieved on 11/5/2020 from“, available at https://www.karriere.de/berufseinstieg-kein-job-ohne-praktikum/23043460.html (accessed 11 May 2020)

Gunawan, W., Creed, P. A., \&. and Glendon, A. I. (2019)-), "Development and initial validation of a perceived future employability scale for young adults:", Journal of Career Assessment, Vol. $27(-$ No. 4), pp. 610-627.

Haustein, B. (2016)-_, „Mitarbeiterbindung in einer öffentlichen Verwaltung“_ [Committment in the Public Sector]. Unpublished Master Thesis], unpublished master thesis, FriedrichAlexander-Universität Erlangen-Nürnberg, Nürnberg.

Heckhausen, J., Wrosch, C., \&.. and Schulz, R. (2010)-.), “A motivational theory of life-span development:", Psychological Review, Vol. 117- No. 1), pp. 32-60.

High Fliers Research (2017)-., “The Graduate Marketgraduate market in 2017. Annual review of graduate vacancies \& starting salaries at Britain's leading employers: Downloaded on 12/7/2017 from", available at 
https://www.highfliers.co.uk/download/2017/graduate_market/GMReport17.pdf (accessed 12 July 2017)

Hirschi, A. (2012)-. „“ “The career resources model: Anan integrative framework for career counsellors:-”, British Journal of Guidance \& Counselling, Vol. 40(№. 4), , pp. 369-383

Höge, T., Brucculeri, A-, \&. and Iwanowa, A. N. (2012)-.), "Karriereunsicherheit, Zielkonflikte und Wohlbefinden bei Nachwuchswissenschaftlerinnen und wissenschaftlern:“_,Zeitschrift für Arbeits-_und Organisationspsychologie, Vol. 56, No. 4, pp. 159-172.

Imai, K., Keele, L., \&. and Tingley, D. (2010)-., “A general approach to causal mediation analysis.”, Psychological Methods, Vol. 15,_No. 4, pp. 309-_334.

Inceoglu, I., Selenko, E., McDowall, A., \&_. and Schlachter, S. (2019).(.), “(How) Do work placements work? Scrutinizing the quantitative evidence for a theory-driven future research agenda:=, Journal of Vocational Behavior, Vol. 110, Part B, pp. 317-337.

International Labour Organization (2017)-_, World employment and social outlook. Trends 2017-, ILO: Geneva: ILO. Downloaded, available at http://www.ilo.org/wcmsp5/groups/public/---dgreports/---dcomm/--publ/documents/publication/wcms_541211.pdf (accessed 12/7/ July 2017from: http://www.ilo.org/wemsp5/groups/public/_dgreports/_deomm/publ/documents/publication/wems 541211.pdf)

Jackson, D. (2013)-.), “The contribution of work-integrated learning to undergraduate employability skill outcomes:", Asia-Pacific Journal of Cooperative Education, Vol. 14(No. 2), pp. 99-115.

Jodlbauer, S., Selenko, E., Batinic, B_, \&. and Stiglbauer, B. (2012)-.), "The relationship between job dissatisfaction and training transfer:-, International Journal of Training and Development,- Vol. $16($ No. 1), pp. 39-53. 
Jones, F. R., Mardis, M. A., McClure, C. R., Ma, J., Ambavarapu, C-, \&. and Spears, L. I. (2017).), “Work-integrated learning (WIL) in information technology.", Higher Education, Skills and Work-Based Learning, Vol. 7(-No. 4), pp. 394-407.

Judge, T. A., Thoresen, C. J., Bono, J. E., \&. and Patton, G. K. (2001)-.), “The job satisfaction-job performance relationship: Aa qualitative and quantitative review-", Psychological Bulletin, Vol. 127(-No. 3), pp. 376-407.

Jung, Y, \& . and Takeuchi, N. (2018)..), “A lifespan perspective for understanding career selfmanagement and satisfaction: Thethe role of developmental human resource practices and organizational support:", Human Relations, Vol. 71(-No. 1), pp. 73-102.

Kapareliotis, I., Voutsina, K., \&.. and Patsiotis, A. (2019).), “Internship and employability prospects: assessing student's work readiness.", Higher Education, Skills and WorkBased Learning, Vol. $9($ No. 4), pp. 538-549.

Kelly, K. R., \&. and Lee, W. C. (2002).), "Mapping the domain of career decision problems:.", Journal of Vocational Behavior, Vol. 61(-No. 2), pp. 302-326.

Lazarus, R. S., \&. and Folkman, S (1984)-_, Stress, appraisal and coping.New York, NY: Springer Publishing Company, New York, NY.

Liu, S., Huang, J. L., \&. and Wang, M. (2014).), "Effectiveness of job search interventions: Aa meta-analytic review:", Psychological Bulletin, Vol. $140(-$ No. 4), pp. 1009-1041. Lucas, W. A., Cooper, S. Y., Ward, T., \&. and Cave, F. (2009)-.), "Industry placement, authentic experience and the development of venturing and technology self-efficacy=", Technovation, Vol. 29(№. 11), pp. 738-752.

Macewen, K. E., Barling, J., Kelloway, E. K_, \&. and Higginbottom, S. F. (1995)-_), "Predicting retirement anxiety: Thethe roles of parental socialization and personal planning.", The Journal of Social Psychology, Vol. 135(№. 2), , pp. 203-213.

McManus, A., \&. and Feinstein, A. H. (2014, January).), "Internships and occupational socialization: Whatwhat are students learning??", Developments in Business Simulation 
and Experiential Learning: Proceedings of the Annual ABSEL Conference, Vol. 35, pp. 128-137.

Mason, G., Williams, G., \&. and Cranmer, S. (2009)-.), "Employability skills initiatives in higher education: what effects do they have on graduate labour market outcomes??", Education Economics, Vol. 17(-No. 1), pp. 1-30.

Massenberg, A. C., Spurk, D.,\&. and Kauffeld, S. (2015).-), "Social support at the workplace, motivation to transfer and training transfer: a multilevel indirect effects model.", International Journal of Training and Development, Vol. 19(-No. 3), pp. 161-178.

Mauno, S., Leskinen, E-, \&. and Kinnunen, U. (2001)-. _, "Multi-wave, multi-variable models of job insecurity: applying different scales in studying the stability of job insecurity.", Journal of Organizational Behavior, Vol. 22(-No. 8),, pp. 919-937.

Messer, D. (2018).), “Work placements at 14-15 years and employability skills:", Education + Training, Vol. 60(-No. 1), pp. 16-26.

Montoya, A. K. (2020).), The power of design: Impactimpact of experimental design outweighs impact of inferential methods on statistical power to detect indirect effectsPreprint, preprint available at https://psyarxiv.com/gqryz/. doi:10.31234/osf.io/gqryz

Nabi, G. R. (2003)-), “Graduate employment and underemployment: opportunity for skill use and career experiences amongst recent business graduates:", Education ${ }^{+}+\underline{+}$ Training, Vol. 45 , No. 7, pp. 371-382.

Neelam, N., Bhattacharya, S., Kejriwal, V., Bhardwaj, V., Goyal, A., Saxena, A., Dhawan, D., Vaddi, A., \&. and Choudaha, G. (2019)-.), "Internship in a business school: expectation versus experience.”, Higher Education, Skills and Work-Based Learning, Vol. $9($ No. 1$)$, pp. $92-106$.

Newman, J. L., Fuqua, D. R., \& and Seaworth, T. B. (1989)-.), “The role of anxiety in career indecision: Implicationsimplications for diagnosis and treatment.", The Career Development Quarterly, Vol. 37(-No. 3), pp. 221-231. 
Nunley, J. M., Pugh, A., Romero, N.,\&. and Seals, R. A. (2017)..), “The effects of unemployment and underemployment on employment opportunities: Resultsresults from a correspondence audit of the labor market for college graduates.", ILR Review,

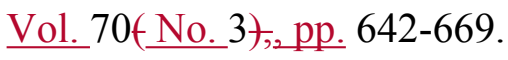

Page, L. (2014)-. , "How to deal with employability anxiety:", The Guardian, Monday $19^{\text {th }}$ May 19.05.2014. Downloaded 12/7/2017 from: https://www.theguardian.com/education/2014/may/19/employment-anxiety-studentsjob-worry, available at

https://www.theguardian.com/education/2014/may/19/employment-anxiety-studentsjob-worry

Pan, J., Guan, Y., Wu, J., Han, L., Zhu, F., Fu, X.,\&. and Yu, J. (2018).), “The interplay of proactive personality and internship quality in Chinese university graduates' job search success: Thethe role of career adaptability-", Journal of Vocational Behavior, Vol. 109, pp. 14-26.

Podsakoff, P. M., MacKenzie, S. B., Lee, J. Y., \&. and Podsakoff, N. P. (2003)-), “Common method biases in behavioral research: Aa critical review of the literature and recommended remedies.", Journal of Applied Psychology, Vol. 88(-No. 5), pp. 879903.

R Core Team (2019)..., The TR project for statistical computing. Downloaded from https://cran.r-project.org/bin/windows/base/old/3.6.1t, available at https://cran.rproject.org/bin/windows/base/old/3.6.1/

Reddy, $\mathrm{P}, \&$. and Moore, E. (2012)-.), "Placement year academic benefit revisited: effects of demographics, prior achievement and degree programme.", Teaching in Higher Education, Vol. 17(-No. 2), pp. 153-165.

Reidy, T. (2020). -2, “'Recruitment is on hold'. The students graduating into the Covid-19 recession:", The Guardian, 10.4.2020, retrieved from: 
https://www.theguardian.com/education/2020/apr/10/recruitment-is-on-hold- thestudents-graduating-into-the-covid-19-recessionavailable at https://www.theguardian.com/education/2020/apr/10/recruitment-is-on-hold-the$\underline{\text { students-graduating-into-the-covid-19-recession }}$

Reschly, A. L., Huebner, E. S., Appleton, J. J.,\&. and Antaramian, S. (2008)-), “Engagement as flourishing: Thethe contribution of positive emotions and coping to adolescents' engagement at school and with learning.., Psychology in the Schools, Vol. 45(-No. 5), pp. 419-431.

Rose, P. S. (2018)-.), “The intern to employee career transition: Anan outsiders perception of insider status.", Journal of Career Development, Vol. 45(- No. 6), pp. 566-579.

Rothwell, A., Herbert, I., \&. and Rothwell, F. (2008)-), "Self-perceived employability: Constructionconstruction and initial validation of a scale for university students:", Journal of Vocational Behavior, Vol. $73($ No. 1), pp. 1-12.

Russell, J. A. (1980)-.), “A circumplex model of affect.”, Journal of Personality and Social Psychology, Vol. 39, No. 6, pp. 1161-1178.

Salancik, G. R., \&. and Pfeffer, J. (1978)-.), “A social information processing approach to job attitudes and task design:”, Administrative Science Quarterly, Vol. 23(№. 2), pp. 224253.

Spurk, D., Kauffeld, S., Meinecke, A. L., \&. and Ebner, K. (2016)-. , "Why do adaptable people feel less insecure? Indirect effects of career adaptability on job and career insecurity via two types of perceived marketability.", Journal of Career Assessment, Vol. 24(№. 2), , pp. 289-306.

Staw, B. M., Sandelands, L. E., \&. and Dutton, J. E. (1981)-.), "Threat rigidity effects in organizational behavior: Aa multilevel analysis:", Administrative Science Quarterly, Vol. 26(-No. 4), , pp. 501-524. 
Stead, G. B.,\&. and Watson, M. B. (1993).,., How similar are the factor structures of the Career Decision Scale, the Career Decision Profile, and the Career Factors Inventory???", Educational and Psychological Measurement, Vol. 53, No. 1, pp. 281290.

Taylor, A.R.,\&. and Hooley, T. (2014).), "Evaluating the impact of career management skills module and internship programme within a university business school.”, British Journal of Guidance \& Counselling, Vol. 42(-No. 5), pp. 487-499.

Thorley, C. (2017)-. „Not by degrees. Improving student mental health in the UK's universities. London:", Institute for Public Policy Research-Retrieved from https://www.ippr.org/files/2017-09/1504645674_not-by-degrees-170905.pdf, London, available at https://www.ippr.org/files/2017-09/1504645674_not-by-degrees$\underline{170905 . p d f}$

Van der Werff, S., \&. and Bisschop, P. (2016)-.), „Studie en Werkwerk. SEO Economisch Onderzoek.economisch onderzoek”, SEO-rapportnummer 2016-47. Downloaded, available at http://www.seo.nl/uploads/media/2016-47_Studie_Werk_2016.pdf (accessed 12/7/2017 from: http://www.seo.nl/uploads/media/201647 Studie_Werk_2016.pdf July 2017)

Van Emmerik, I. J. H., Schreurs, B., De Cuyper, N., Jawahar, I. M., \&_. and Peeters, M. C. (2012)-., "The route to employability: Examiningexamining resources and the mediating role of motivation:", Career Development International, Vol. $17\left(\mathrm{No}_{2}\right)^{2}, \mathrm{pp}$. 104-119.

Van Hootegem, A., Niesen, W-, \&. and De Witte, H. (2019).-), "Does job insecurity hinder innovative work behaviour? A threat rigidity perspective:", Creativity and Innovation Management, Vol. 28(-No. 1), pp. 19-29. 
Warr, P., Bindl, U. K., Parker, S. K., \&. and Inceoglu, I. (2014).), "Four-quadrant investigation of job-related affects and behaviours-", European Journal of Work and Organizational Psychology, Vol. 23(№. 3), pp. 342-363.

Wendlandt, N. M., \&. and Rochlen, A. B. (2008)-), “Addressing the college-to-work transition: Implicationsimplications for university career counselors:", Journal of Career Development, Vol. 35(-No. 2), pp. 151-165.

Wilton, N. (2012).), "The impact of work placements on skills development and career outcomes for business and management graduates:", Studies in Higher Education, Vol. $37(-$ No. 5), pp. 603-620.

Zehr, S. M,,\&. and Korte, R. (2020)-), “Student internship experiences: learning about the workplace:", Education + Training, Vol. 62(-No. 3), pp. 311-324.

Zumrah, A. R., \&. and Boyle, S. (2015)-.), "The effects of perceived organizational support and job satisfaction on transfer of training.”, Personnel Review, Vol. $44(\underline{\text { No. }} 2)$, pp. 236-254. 
